\title{
GEOPROCESSAMENTO COMO ESTRATÉGIA DE INVESTIGAÇÃO DO ESPAÇO GEOGRÁFICO: UMA ABORDAGEM SOCIOAMBIENTAL APLICADA AO TERRITÓRIO DE IDENTIDADE SERTÃO DO SÃO FRANCISCO (BA), 2004 A $2006^{1}$
}

\author{
Marcia Aparecida Procopio da Silva Scheer ${ }^{2}$ \\ Creuza Santos Lage ${ }^{3}$ \\ Emanuel Fernando Reis de Jesus ${ }^{4}$ \\ Neyde Santos Gonçalves ${ }^{5}$ \\ Noeli Pertille ${ }^{6}$ \\ Denise Silva Magalhães ${ }^{7}$ \\ Danilo Melo \\ Thiago de Aquino Pires
}

Resumo: As regiões tropicais semiáridas correspondem a ecossistemas frágeis, $e$, conseqüentemente, susceptíveis a processos de degradação socioambientais com efeitos significativos na vulnerabilidade local e com repercussões sobre a sustentabilidade de seus territórios. A deficiência hídrica atua como fator restritivo e dificulta as condições biostásicas do sistema natura, I com importantes impactos na qualidade de vida das comunidades dessas regiões. A adversidade climática, sobretudo quanto aos riscos de seca, à salinização dos solos, às práticas agrícolas inadequadas, aliados à concentração da propriedade da terra e ao acesso ao uso produtivo da água, os altos índices de pobreza, a exclusão social são exemplos, entre outros, da fragilidade socioambiental de extensas áreas do semiárido baiano, com graves consequências para a economia local. Inserido neste contexto, o presente projeto teve o objetivo de analisar a vulnerabilidade e as perspectivas de sustentabilidade do Território de Identidade Sertão do São Francisco (BA), (implantado pela Secretaria do Desenvolvimento Territorial - Ministério do Desenvolvimento Agrário) em 2005, por meio de uma metodologia de integração em ambiente de Sistema de Informação Geográfica, a partir de indicadores ambientais (escassez hídrica por meio de dados meteorológicos), sociais (população e estrutura fundiária), econômicos (produção agrícola) e político/institucionais

\footnotetext{
${ }^{1}$ Colaboradores: Prof. Dr. Jansle Vieira Rocha - FEAGRI/UNICAMP; Profa. Dra. Guiomar Inez Germani - IGEO/UFBA; Ms. Paula Adelaide Mattos Santos Moreira - INCRA/Bahia. Agradecimento especial: Profa. Dra. Rosângela Leal/UEFS; Prof Dr. José Fernando Souto Júnior/UNIVASF; Profa Dra Regina Celeste Souza/ UNIFACS.

${ }^{2}$ IGEO/UFBA (coordenadora), Professora Adjunto IV do Instituto de Tecnologia, Infraestrutura e Território da Universidade Federal da Integração Latino Americana - UNILA - Foz do Iguaçu - PR.

${ }^{3}$ Possui graduação em Geografia pela Universidade Federal da Bahia (1969), Mestrado em Geociências, opção Geomorfologia pela Universidade Federal da Bahia (1980) e Doutorado em Geografia - Université de Bordeuaux III (1986). Atualmente é Professor Associado Aposentado, com atuação junto ao Mestrado em Geografia do Instituto de Geociências da UFBA.

${ }^{4}$ Possui Licenciatura em Geografia pela Universidade Católica do Salvador (1977), Mestrado em Geociências (Geomorfologia) pelo Instituto de Geociências da Universidade Federal da Bahia (1984) e DOUTORADO em Geografia Física (Climatologia) pela Universidade de São Paulo USP (1995). Atualmente é Professor Associado do Departamento e do Programa de Pós-Graduação em Geografia (Mestrado e Doutorado) do Instituto de Geociências da Universidade Federal da Bahia

${ }^{5}$ Possui graduação em Geografia pela Universidade Católica do Salvador (1963), Mestrado em Ciências Sociais pela Universidade Federal da Bahia (1971) e Doutorado em Geografia (Geografia Física) pela Universidade de São Paulo (1992). Atualmente é Professor Adjunto IV Departamento de Geografia do Instituto de Geociências da UFBA.

${ }^{6}$ Possui Graduação (Bacharelado e Licenciatura, 1998), Mestrado (2001) e Doutorado (2008) em Geografia pela Universidade Federal de Santa Catarina (UFSC). Atualmente é Professora Adjunto III na Universidade Federal da Bahia.

${ }^{7}$ Possui Graduação em Geografia pela Universidade Federal da Bahia - UFBA/Salvador (1974); Especialização em Cartografia Básica pela Cartographic School Defense Mapping Agency/Inter American Geodetic SURVEYIAGS/Panamá (1974); Mestrado em Análise Regional pela Universidade Salvador UNIFACS (2003); Aluna regular do Doutorado em Geografia da UFBA. Atualmente é professora Assistente IV da Universidade Federal da Bahia.
} 
(PRONAF), visando apresentar alternativas que contribuam para a compreensão desses problemas formulando, assim, diagnósticos positivos que impulsionem ações para sua resolução. Os materiais utilizados a priori foram: dados do meio físico, dados da Produção Agrícola Municipal (PAM- IBGE), dados referentes as verbas do Programa Nacional de Fortalecimento da Agricultura Familiar (PRONAF) e imagens de satélite SPOT 4 -Vegetation. Deve-se destacar que, é muito importante a realização deste tipo de pesquisa na área de estudo por ela abranger significativa extensão territorial, cujo perfil agrícola dá suporte a duas realidades distintas: primeira, a produção de frutas para exportação e outros produtos agrícolas destinados à indústria e, segunda, a produção familiar e de subsistência que sofrem diretamente com as adversidades do local. Também, foi considerada a discussão em âmbito nacional, quanto às políticas públicas emanadas quanto ao uso racional da água e a Transposição do Rio São Francisco, como também quanto a incentivos visando o aumento da produtividade local e de questões quanto a garantia da Soberania Alimentar para população local. A abordagem metodológica desta pesquisa foi quali-quantitativa e o referencial teórico metodológico teve como base estudos de Raffestin (1993), Silva (2003) e Santos (2006) na análise do Território, Drew (1986) e Christofoletti (1999) no estudo dos sistemas ambientais, Ayyar (1969) e Gerardi (1981) quanto às técnicas de classificação estatística, Novo (1988) e Crosta (1999) no tratamento das imagens orbitais, e Burrough (1986) e Assad (1993) quanto ao Sistema de Informação Geográfica, entre vários outros autores importantes para o desenvolvimento da pesquisa. Como resultado final, foi elaborado um banco de dados integrado (numérico e espacial) em ambiente de SIG, de fácil manipulação, que possibilitou a realização de análises e correlações sobre a área de estudo. Foram previstos como produtos desta pesquisa a caracterização dos sistemas produtivos; o mapeamento das áreas que sofrem com a escassez hídrica, a elaboração de uma metodologia de estudo fundamentada na formulação de indicadores com o uso de ferramentas de Geoprocessamento passível de ser aplicada futuramente em toda a Bahia. Deve-se ressaltar que, a originalidade desta proposta consiste no esforço de articulação de diferentes metodologias de análise, visando o desenvolvimento de um modelo que possibilite melhores aproximações analíticas da realidade. Com a conclusão desta pesquisa, pretende-se aprofundar as análises geradas até o momento, aprimorar conceitos relacionados às novas situações vivenciadas e também colaborar no processo de planejamento com a difusão do conhecimento sobre a convivência com o semiárido, por exemplos: confecção de uma cartilha paradidática feita pelos alunos da graduação da UFBA sobre o assunto e a execução de oficinas organizadas pelo intermédio de Órgãos Públicos, Organizações não governamentais e religiosas, integrando assim as diversas visões sobre realidade da área de estudo neste próximo ano.

Palavras-Chave: Semiárido, Escassez Hídrica, PRONAF, Produção Agrícola, SPOT 4Vegetation.

\section{INTRODUÇÃO}

"O homem dos sertões (...) mais do que qualquer outro, está em função imediata da terra. É uma variável dependente no jogar dos elementos". (CUNHA, E. Os Sertões, 1901, p.03) 
A dinâmica de ocupação nas terras da região Nordeste do Brasil se deu de forma desigual. As atividades agrícolas, por exemplo, concentravam-se na costa litorânea, tratava- se do cultivo da cana-de-açúcar, cultura que movimentava a economia no período do Brasil colônia.

O interior da região, em especial o semiárido, apresentava-se como uma lacuna. Devido as suas condições climáticas pouco favoráveis ao plantio, o sertão ficou por muito tempo despovoado e sem nenhum atrativo econômico. Em razão de suas peculiaridades naturais que refletem no âmbito social, o semiárido nordestino há tempos é objeto de estudo de diversos trabalhos acadêmicos e de órgãos do Governo que visam obter maiores conhecimentos desta área tão ímpar do espaço brasileiro.

A região semiárida é caracterizada por adversidades climáticas, sobretudo as secas. Suas isoietas circunscrevem abaixo de $800 \mathrm{~mm}$ de pluviosidade anual. As chuvas são concentradas, porém ocorrem num curto período de tempo, sendo que a maior parte do ano é caracterizada por estiagens.

O estado da Bahia, ao longo de sua história, tem sido palco das mudanças ocorridas no processo produtivo da agricultura. Apesar do nível tecnológico alcançado em algumas regiões do país, a atividade agrícola do estado continua bastante dependente da dinâmica e da variabilidade natural do clima.

Neste cenário de inúmeras implicações ambientais está localizado o Território de Identidade Sertão do São Francisco ocupando a porção setentrional do estado da Bahia, na Bacia do Rio São Francisco. Com uma área de $61.765,61$ km² $^{2}$ e uma população estimada em 507.782 habitantes (IBGE, 2007), suas terras estão totalmente inseridas no semiárido,

Trata-se de uma das áreas mais problemáticas da Bahia, não somente pelos aspectos de semiaridez, como também pelas questões socioeconômicas e culturais. Apesar da vulnerabilidade no que se refere aos seus aspectos físicos, o clima quando conjugado com a agricultura irrigada passa a ser um fator favorável para o sucesso da produção que favorece, por sua vez, a qualidade dos cultivos. Sendo assim, é a partir da perspectiva da produção agrícola que se fundamenta esta pesquisa.

Embora tenha grande peso na economia do estado, o perfil agrícola da área de estudo apresenta duas vertentes distintas: a primeira refere-se à produção de frutas para exportação apoiada no que há de mais moderno para o cultivo e colheita e, a segunda está 
relacionada à agricultura de subsistência e familiar, cuja sua produção está permanentemente em risco por conta das adversidades climáticas.

O Governo Federal preocupado com a situação do pequeno produtor implantou em 1996 o Programa Nacional de Fortalecimento da Agricultura Familiar (PRONAF) o que propiciou intensas transformações na composição do campo no Brasil.

O PRONAF tem como principal objetivo apoiar financeiramente o trabalhador rural que possui emprego de mão-de-obra familiar integrando-o ao agronegócio. Este apoio financeiro é feito via concessão de créditos para investimentos na produção, sendo assim, o pequeno agricultor pode utilizar os recursos disponibilizados para adquirir máquinas e equipamentos, por exemplo, que favorecerão no desenvolvimento de suas atividades.

Sabendo-se da importância do PRONAF como mediador para o desenvolvimento da agricultura familiar, percebe-se o seu papel significativo, sendo que, na Bahia desde a sua implantação na década de 1990 até o ano de 2004 houve uma considerável transformação na composição do campo, no que se refere à produção, neste mesmo período, houve um aumento no seu montante de $\mathrm{R} \$ 3$ bilhões para $\mathrm{R} \$ 1$ 16,6 bilhões (AVENA, 2006).

Pretendeu-se, portanto, verificar se essas mudanças do campo também ocorreram de modo substancial nos municípios componentes do Território de Identidade Sertão do São Francisco, além de analisar as transformações da prática agrícola com os eventos de seca, relacionando estes fatos com os dados da produção agrícola e as aplicações das verbas do PRONAF no período analisado.

Não pode deixar de mencionar que a idéia inicial para a realização desta pesquisa partiu do Prof. Dr. Jansle Vieira Rocha, coordenador do Grupo de Estudos em Geoprocessamento (FEAGRI/UNICAMP), que trabalhou entre 2005 e 2007 na Comissão Européia (Joint Research Centre), Ispra - Itália e que trouxe para o Brasil a proposta de combinar imagens orbitais SPOT 4- VGT com dados econômicos, sociais e ambientais em locais onde há escasses hídrica. Assim, numa parceria UFBA/IGEO (pois o professor foi o orientandor de doutorado da coordenadora desta pesquisa) e a UNICAMP/FEAGRI deu-se início a presente pesquisa.

Deve-se destacar tal interesse pelo assunto, porque nas análises feitas pelo JRC nos últimos anos o Brasil dispõe de alimentos suficientes para sua população, sendo considerado seguro quanto a Soberania Alimentar, porém na realidade, o que verifica-se é a má distribuição e 
também a perda de alimentos por falta de planejamento no plantio, azares climáticos e pela má conservação no transporte dos mesmos.

\title{
Universo da Pesquisa
}

\begin{abstract}
"Conhecer mais adequadamente o complexo geográfico e social dos sertões secos e fixar os atributos, as limitações e as capacidades dos seus espaços ecológicos nos parece uma espécie de exercício de brasilidade, o germe mesmo de uma desesperada busca de soluções para uma das regiões socialmente mais dramáticas das Américas". (AB'SABER. A. Dossiê Nordeste Seco. Estudos Avançados 13(36), 1999, p.05).
\end{abstract}

Segundo Ab'Saber (1999, p.7)

"o nordeste seco possui uma área total da ordem de $700 \mathrm{mil} \mathrm{km}^{2}$, onde vivem 23 milhões de brasileiros... A análise das condicionantes do meio natural constitui uma prévia decisiva ára explicar causas básicas de uma questão que se insere no cruzamento dos fatos físicos, ecológicos e sociais. Nenhuma solução ou feixe de soluções dirigidas para a resolução dos problemas do nordeste brasileiro poderá abstrair o comportamento de seu meio ambiente, inclusive no que diz respeito à fisiologia da paisagem, aos tipos de tecidos ecológicos e à utilização adequada dos escassos recursos hídricos disponíveis".

$\mathrm{Na}$ decisão do recorte desta pesquisa o grupo se deparou com a divisão comumente trabalhada nos Órgãos do Estado: Territórios de Identidade da Bahia, implantados pela Secretaria do Desenvolvimento Territorial - Ministério do Desenvolvimento Agrário, em 2005, realizado por meio de uma metodologia de integração a partir de afinidades de indicadores ambientais, sociais, econômicos e político-institucionais,

Neste âmbito, a escolha dos professores pesquisadores e colaboradores ao formularem o Projeto de Pesquisa foi "Geoprocessamento como estratégia de investigação do espaço geográfico: uma abordagem socioambiental aplicada ao Território de Identidade Sertão do São Francisco (BA), 2004 a 2006", coordenado pela Profa. Dra. Marcia Aparecida da Silva Scheer. Este projeto teve início em meados de 2008 com a elaboração do projeto no Laboratório de Estudos Ambientais e Gestão do Território (LEAGET) do Mestrado em Geografia/Departamento de Geografia/IGEO/UNIVERSIDADE FEDERAL DA BAHIA. 
Resumidamente, destaca-se que mais de $60 \%$ de área do estado da Bahia está incluído no trópico semiárido, sujeito às irregularidades nas precipitações pluviométricas anuais, caracterizando-se pela extrema variabilidade têmporo-espacial. Também aliado a adversidade climática estão os índices de pobreza, da exclusão social, entre outros, que são exemplos da fragilidade socioambiental de extensas áreas com graves consequências para a sobrevivência no local.

A presente área de estudo Território de Identidade Sertão do São Francisco - BA (Figura 1), ao Norte do estado da Bahia é composto pelos municípios: Campo Alegre de Lourdes, Canudos, Casa Nova, Curaçá, Juazeiro, Pilão Arcado, Remanso, Sento Sé, Sobradinho e Uauá. Tal região apresenta altos índices de semiaridez e relevantes questões envolvendo problemas socioeconômicos, porém é possuidora de uma riqueza incalculável culturalmente.

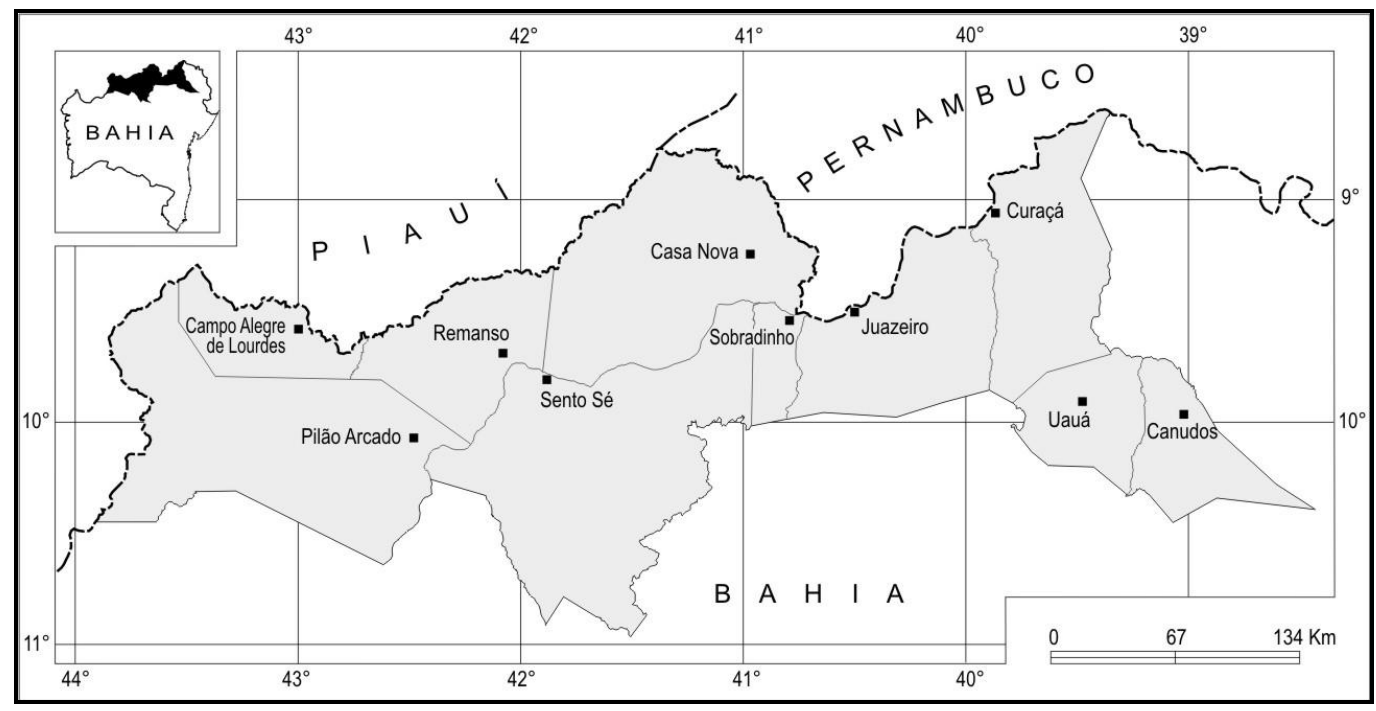

Fonte: SEI/SEPLAN, 2010.

Figura 1: Território de Identidade Sertão do São Francisco (BA), 2010.

Segundo tipologia climática proposta por Thorntwaite \& Matther - média pluviométrica de 1943 a 1983 e a temperatura média referente ao período de 1961 a 1990 - aplicada ao estado da Bahia em decorrência do conhecimento da realidade da área, pode-se classificar o clima da região como Tropical Semi-Árido, com forte tendência à semi-aridez em função da extrema irregularidade das chuvas ao longo do ano, com totais anuais inferiores a $750 \mathrm{~mm}$ (nenhum excedente hídrico, megatérmico, evapotranspiração potencial $>1.140 \mathrm{~mm}$, com chuvas de primavera/verão). 
De forma geral as temperaturas médias compensadas anuais das sedes municipais, registram elevadas temperaturas (24ㅇ a $26 \% \mathrm{C}$ ), intenso índice de evaporação ao longo do ano e índice hídrico anual variando de -20 a -40\%. (SEI, 1998).

De acordo com esta situação os recortes feitos para o Território a partir das imagens SPOT 4 - Vegetation ${ }^{8}$ refletem, no ano de 2004, os meses de março e novembro, respectivamente sem escassez hídrica e com escassez hídrica.

A bacia hidrográfica do Rio São Francisco (Figura 03), é a maior do estado, ocupando uma área de $304.421 \mathrm{~km}^{2}$ de extensão. Na Bahia, sua bacia de drenagem corresponde ao médio (área que também engloba o Território Sertão do São Francisco) e baixo curso, abrangendo áreas a Oeste, parte da região Central e Norte do Estado.

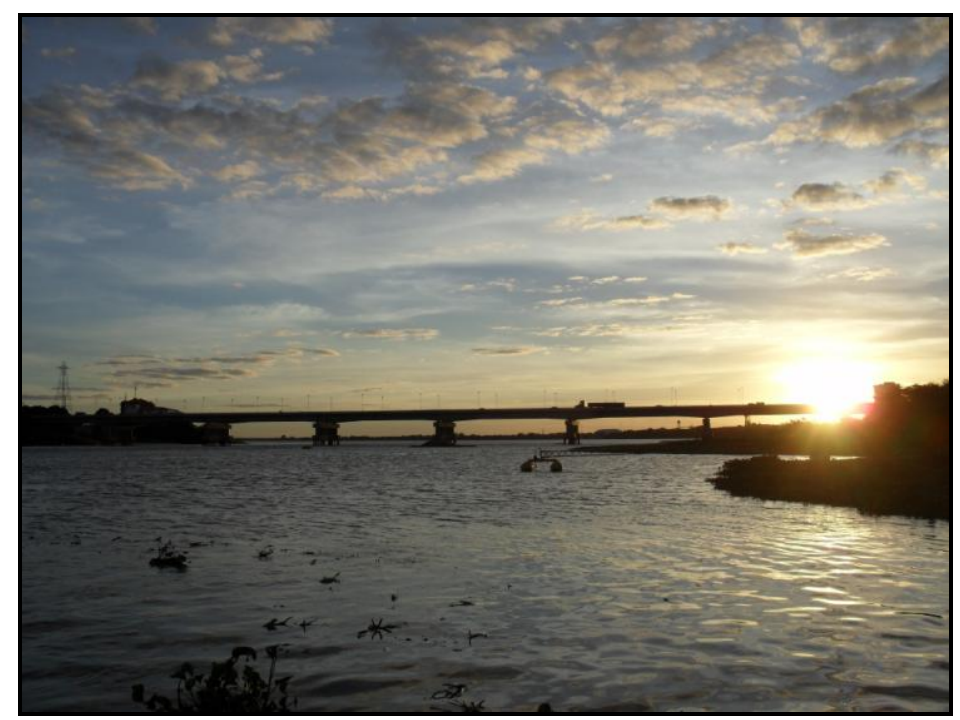

Fonte: Trabalho de campo, 2010.

Figura 2: Rio São Francisco entre Juazeiro (BA) e Petrolina (PE), 2010.

A vazão do Rio São Francisco é maior nos meses de janeiro a março no período das chuvas de verão e a menor vazão ocorre nos meses de agosto e outubro quando o rio atinge as cotas mais baixas, período de estiagem e maior evaporação.

A área de estudo situa-se, principalmente, na bacia hidrográfica do Rio São Francisco, abrangendo áreas de nove municípios. Os principais cursos d'água, da área, na margem direita do Rio São Francisco são os Rio Verde, o Jacaré ou Vereda do Romão Gramacho,

\footnotetext{
${ }^{8}$ Para o Projeto do PIBIC 2008/2009, o aluno voluntário Thiago de Aquino Pires realizou o recorte da área de estudo a partir das 86 imagens SPOT 4 - Vegetation, do triênio 2004 a 2006. Referente ao ano de 2004 foram processadas e manipuladas 12 imagens (uma para cada 10 dias). O tratamento digital e interpretação das imagens orbitais, auxiliado pelo índice NDVI, permitiram a identificação dos locais que sofrem com escassez hídrica.
} 
Salitre e o Curaçá. Riachos e veredas são afluentes tanto da margem direita como esquerda do rio, cuja rede de drenagem é temporária, resultante dos baixos índices pluviométricos da região.

A barragem e usina hidroelétrica de Sobradinho, construídas pela Companhia Hidoelétrica do São Francisco (CHESF) entre o período de 1973 a 1981, vieram suprir às necessidades do Nordeste, região esta grande deficitária de energia, na época em que o país começava a entrar no ritmo da industrialização. A construção desta barragem no Rio São Francisco foi responsável, inicialmente, pelo primeiro surto significativo de imigração para o território para onde se deslocaram umas 60.000 pessoas da região Nordeste em busca de trabalho, mas que ficaram desempregadas com o término da obra, vindo habitar a periferia das cidades de Juazeiro e Petrolina. O Lago de Sobradinho (Figura 03) - maior lago artificial da América Latina e o terceiro do mundo - inundou mais de $4.000 \mathrm{~km}^{2}$ de áreas agrícolas e pecuária na região.

Nos municípios de Sobradinho, Casa Nova, Remanso, Sento Sé e Pilão Arcado afetando mais os quatro últimos que tiveram suas sedes transferidas. A população destas cidades, em torno de 65.000 habitantes, foi desalojada. (CALDAS, 2006).

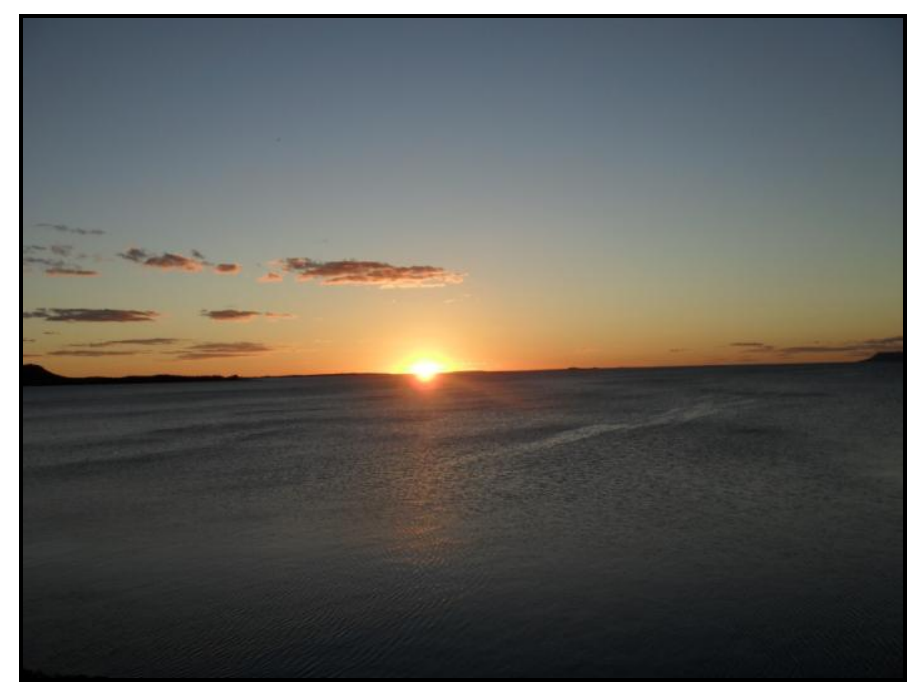

Fonte: Trabalho de campo, 2010

Figura 3: Vista parcial do Lago de Sobradinho, 2010.

"[o] realocamento populacional se deu através da expulsão violenta principalmente dos moradores das áreas rurais, na sua maioria camponeses pobres, que viviam nas barrancas do rio cultivando os solos aluviais das 
ilhas e margens do rio, pescando e criando animais". (BOMFIM, 1999, não paginado).

Relata o autor a forma dramática que se constituiu em tremenda injustiça social com os camponeses sendo expulsos de suas terras sem direito a quase nada, a não ser irrisórias indenizações. De acordo com Caldas (2006) a reação de muitos atingidos que se negavam a deixar suas terras ou emigrar aos grandes centros urbanos do país foi a de reinstalarem-se nas bordas do Lago, sendo empregada a violência pelo comando da Polícia Militar, para desalojá-los.

A CHESF cumpriu à força o seu objetivo de produzir energia para as regiões Norte e Nordeste do país, mas a um elevado custo social, prejudicando parte da população, que até hoje não conseguiu reencontrar seu espaço e seu modo de viver. (CALDAS, 2006, p. 117).

A segunda bacia hidrográfica na qual também está contido o território é a do Rio VazaBarris, com rede de drenagem intermitente. O Rio Vaza-Barris nasce na Serra da Canabrava em Uauá, segue para o município de Canudos, percorre a região Nordeste do estado, direção Oeste-Leste, indo desembocar no Oceano Atlântico, depois de passar pelo vizinho estado de Sergipe. Um dos maiores açudes do estado, o de Cocorobó, está situado no Rio Vaza-Barris no município de Canudos. De igual forma ao Lago de Sobradinho, o Lago de Cocorobó causou impactos, visto que obrigou o relocamento da população da cidade de Canudos, porém não houve possibilidade de visita ao local.

Em meio a contradições econômicas e sociais, em setembro de 2010, foi publicada palestra sobre o Vale do São Francisco. Segundo Souto (2010, inédito):

“...Em caixa alta o título da matéria chama atenção pelo tom religioso e salvacionista: 'O milagre do São Francisco'. A reportagem começa assim: 'no sertão nordestino, a aridez sempre rivalizou com o sonho de fazer da caatinga um enorme e salvador pomar - e assim, tirar seus habitantes da pobreza' Pelo início da matéria percebe-se que o milagre parece ter acontecido. Surpreendentemente, os créditos não foram para o santo, mas para a ditadura: 'nos anos 60, o Vale do São Francisco ganhou atenção dos militares, que vislumbraram a região como um centro de energia e produção de alimentos'. (SOUTO, 2010. / Revista Veja, 10 de setembro de 2010, p. 101). 
Realmente muitas transformações ocorreram ao longo dos anos, porém foi feita de forma seletiva, cujo o produtor teve que se adaptar as novas tecnologias e também a mão de obra especializada. (Figura 4).

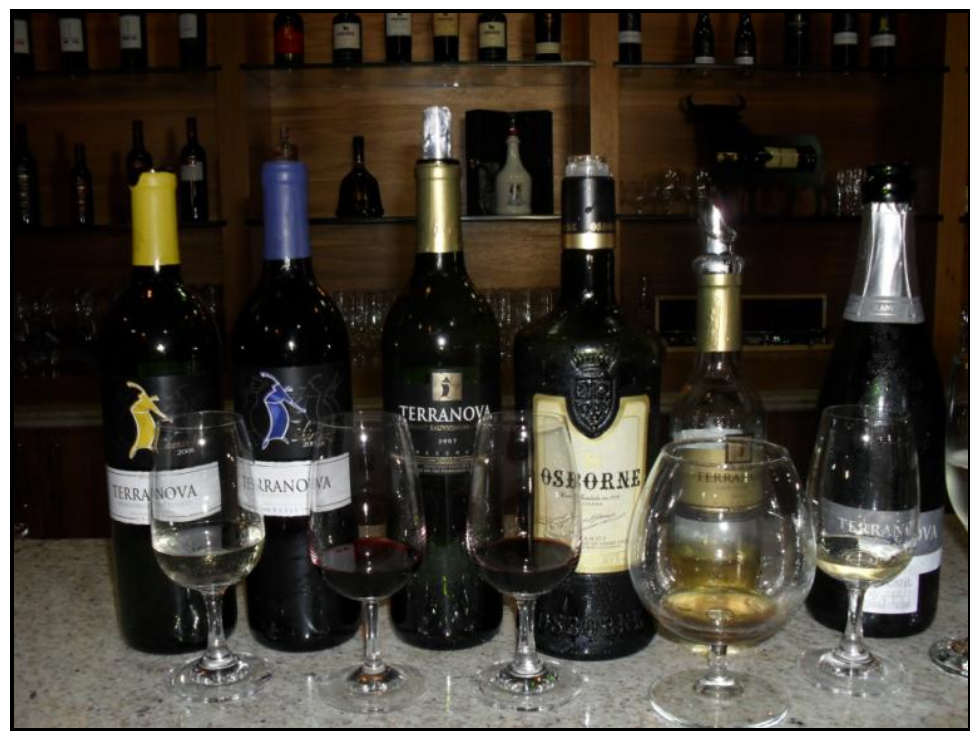

Figura 4: Visita a vinícola Ouro Verde. As Bebidas produzidas são comercializadas nacionalmente e internacionalmente, 2010.

Fonte: Trabalho de campo, 2010.

Elaboração da base cartográfica para o território de identidade sertão do São Francisco (BA)

Sob a coordenação da Profa. Denise Magalhães, alunos voluntários da graduação em Geografia elaboraram a base cartográfica para o Território de Identidade Sertão do São Francisco, segundo as etapas de trabalho:

ETAPA 1: Obtidas na Superintendência de Estudos Econômicos e Sociais da Bahia (SEI), em meio digital, as folhas topográficas ${ }^{9}$ do mapeamento sistemático, no total de 37 (trinta e sete), e duas folhas planimétricas ${ }^{10}$, na escala de $1: 100.000^{11}$; (Figura 10).

\footnotetext{
${ }^{9}$ O mapeamento sistemático topográfico é "elaborado a partir de levantamentos aerofotogramétrico e geodésico original ou compilado de outras cartas topográficas em escalas maiores. Inclui os acidentes naturais e artificiais, em que os elementos planimétricos (sistema viário, obras, etc.) e altimétricos (relevo através de curvas de nível, pontos colados, etc.) são geometricamente bem representados". (IBGE, 1999). Efetuado pelos órgãos responsáveis pela cartografia nacional: Instituto de Geografia e Estatística (IBGE), Diretoria do Serviço Geográfico (DSG) do Ministério do Exército e Superintendência de Desenvolvimento do Nordeste (SUDENE) em convênio com a Companhia de Desenvolvimento do Vale do São Francisco (CODEVASF), durante as décadas de 70 a 80, este mapeamento, relativo ao estado da Bahia, foi convertido, pela Superintendência de Estudos Econômicos e Sociais da Bahia (SEI), do meio analógico para o meio digital, através do processo de vetorização.

${ }^{10}$ Referente ao "vazio cartográfico" do mapeamento sistemático/topográfico do estado da Bahia, na escala de 1:100.000, foram elaboradas oito folhas planimétricas a partir de um convênio SEI/IBGE. O produto mais usual do mapeamento planimétrico "são imagens obtidas a partir da visada vertical georreferenciadas para a projeção cartográfica desejada". (IBGE, 1999). Para este mapeamento do estado da Bahia
} 
ETAPA 2: Com este mapeamento, em Sistema ArcGis, foi possível realizar a compilação com seleção dos layers de hidrografia (principais cursos d'água, Lago de Sobradinho, açudes, represas); hipsografia (curvas de nível, com mudança das equidistâncias das curvas de nível de 40 ou 50 m para 200 m); localidades (cidades e vilas), limites interestaduais e rede viária (rodovias estaduais e federais);

ETAPA 3: Atualização da Base Cartográfica, após georreferenciamento, pelas imagens Landsat 5 ;

ETAPA 4: Edição da Base Cartográfica para representação digital e gráfica, objetivando posterior análise do Território.

A segunda etapa, que sintetiza os procedimentos metodológicos adotados, relativas à execução da base cartográfica a partir da compilação das folhas topográficas, em meio digital, apoiou-se nos seguintes referenciais teóricos: IBGE (1999) e Cêurio de Oliveira (1988). De forma que, os autores foram fundamentais ao andamento dos trabalhos, pois quando da representação dos elementos que compõem a base cartográfica, buscaram-se os símbolos e cores convencionais, tanto os planiméticos, quanto os altimétricos. Os planimétricos elementos que cobrem a superfície do solo, sejam estes físicos ou naturais e culturais ou artificiais - nos primeiros a representação dos elementos hidrográficos e os segundos decorrentes da ocupação humana: o sistema viário, as construções (cidades e vilas) e os limites políticos-administrativos. Os altimétricos representados pelas curvas de nível e pontos cotados.

De igual forma os autores foram basilares quando das várias dificuldades encontradas no decorrer do trabalho. A principal delas, a defasagem deste mapeamento sistemático que data das décadas de 70 e 80, e a necessidade da sua atualização através das imagens de satélites Landsat 5, conforme mencionado na etapa 3. Para exemplificar, folhas foram elaboradas, pela mesma instituição, anterior a inundação do Lago de Sobradinho e outras adjacentes após este evento.

Outra grande dificuldade referiu-se as diferentes eqüidistâncias das curvas de nível que foram estabelecidas no mapeamento básico original - de 40m (nas folhas elaboradas pela

\footnotetext{
foram utilizadas as imagens SPOT na escala de 1:100.000 como fundo, sendo os temas lançados a partir de levantamentos e reambulação em campo.

${ }^{11}$ Segundo o IBGE (1999), o objetivo da carta topográfica na escala 1:100.000 é representar as áreas com notável ocupação, priorizadas para os investimentos governamentais, em todos os níveis de governo - Federal, Estadual e Municipal.
} 
DSG e SUDENE) ou de 50m (nas folhas elaboradas pelo IBGE). De forma que houve a necessidade de se mudar a eqüidistância para $200 \mathrm{~m}$, portanto inadequada a escala de 1:100.000 ${ }^{12}$, mas a única possível para a confecção da base cartográfica em questão.

Outros problemas foram provenientes dos erros encontrados no mapeamento básico topográfico original; na conversão, pela SEI, deste mapeamento do meio analógico para o meio digital (através do processo de vetorização) e das uniões das folhas topográficas, cuja precisão gráfica fica a desejar, visto que ultrapassa, em muitíssimos casos, o erro admissível de $0,2 \mathrm{~mm}$, na escala de 1:100.000 igual a $20 \mathrm{~m}$.

Os problemas foram sendo solucionados no decorrer do trabalho, quase sempre através da leitura e interpretação dos originais das folhas topográficas em meio analógico.

Folhas topográficas do mapeamento sistemático obtidas, em meio digital, pela Superintende̊ncia de Estudos Econômicos e Sociais da Bahia (SEI) e folhas planimétricas, na escala de 1:100.000.

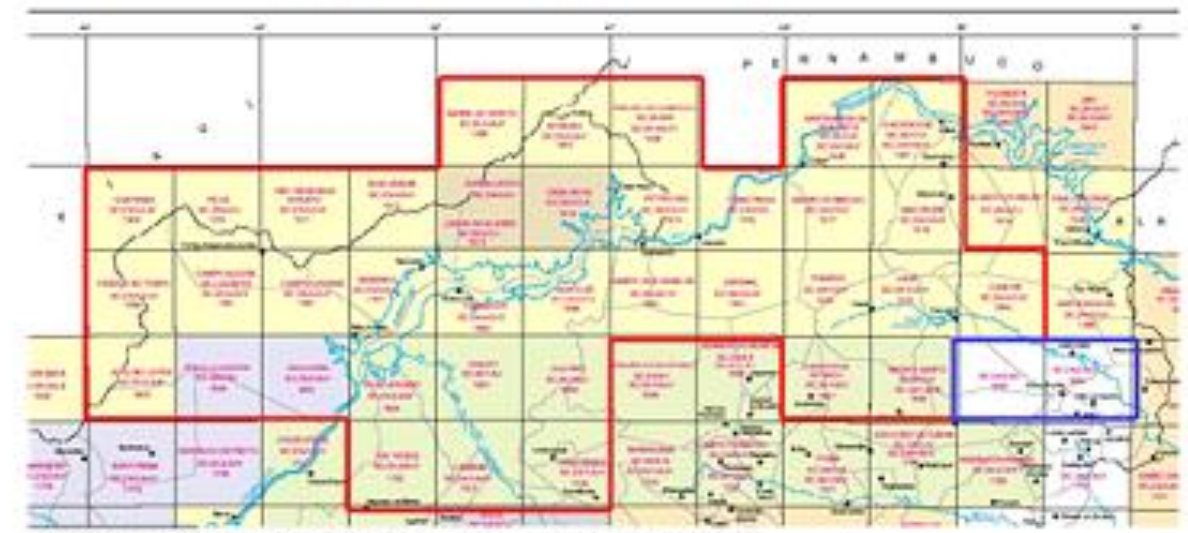

FONTE: Mapa indice das Folhas Topograficas, SEVSEPLAN, 2010 ADAPTADO POR: Denise Magalhales

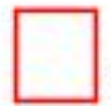

37 folhas topográficas

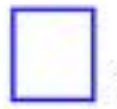

2 folhas planimétricas

Figura 5. Mapa índice das folhas topográficas da área de estudo, 2010.

No caso dos erros de precisão gráfica provenientes das uniões das folhas, os elementos foram unidos visualmente, após análise dos documentos.

Por conta da relevância da modernização cartográfica, decidiu o Governo do Estado da Bahia,

\footnotetext{
${ }^{12} \mathrm{O}$ intervalo das curvas de nível (eqüidistância) é estabelecido em função da escala e da Carta Internacional do Mundo ao milionésimo (CIM). Na escala de 1:100.000 a eqüidistância é de 50m. (OLIVEIRA, 1988).
} 
desde julho de 2007, investir no projeto de Atualização da Cartografia Sistemática através da SEI, com recobrimento cartográfico em escalas grandes, a exemplo de 1:50.000 ${ }^{13}$ para a região do Semi-árido. Releva-se a importância desses produtos que representam enorme avanço na qualidade do acervo cartográfico e coloca a Bahia em posição de vanguarda no Brasil, proporcionando instrumentos de subsídio imprescindíveis para o planejamento e gestão do seu território.

\section{Aspectos climatológicos do Território de Identidade Sertão do São Francisco (BA).}

No contexto intertropical do território do nordeste brasileiro, o estado da Bahia representa aguda de grande diversidade de quadros naturais. Dentre os domínios de paisagens ou de condições morfoclimáticas do país, o bioma caatinga é um dos mais representativos do ponto de vista espacial baiano.

Um dos aspectos que mais singulariza o domínio das caatingas que recobrem as extensas superfícies interplanálticas em relação às demais áreas do estado, contudo, é que seu território está submetido às influências das condições de semiaridez proporcionadas pela extrema irregularidade temporal e espacial das chuvas ao longo do ano.

O semiárido nordestino, em linhas gerais fica situado em posição marginal relativamente aos ambientes de climas áridos e semiáridos tropicais e subtropicais do globo. Segundo Ab'Saber (1974), os climas do sertão nordestino constituem-se exceção em relação aos denominados climas zonais peculiares às faixas de latitudes similares. Pode ser considerado, neste sentido, como um clima azonal, de grande expressão intra-regional, afetando mais de $70 \%$ do estado da Bahia.

Os sistemas de circulação atmosférica atuantes sobre o referido estado, desempenham um papel de extrema relevância sobre a dinâmica do clima regional nas suas diversas escalas espaciais.

O estado da Bahia, em especial, do ponto de vista climatológico, é caracterizado numa complexa organização climática, face a sua posição geográfica no contexto do país, ou seja, ocupa juntamente com o nordeste brasileiro uma faixa transicional frente aos mecanismos

\footnotetext{
${ }^{13}$ A escala de 1:50.000 retrata cartograficamente zonas densamente povoadas, sendo adequada ao planejamento socioeconômico e à formulação de anteprojetos de engenharia. (IBGE, 1999).
} 
dos sistemas de circulação meteorológicos atuantes.

O setor norte do estado, onde situa-se a região denominada de Território de Identidade do São Francisco, representa uma das áreas cujas as condições de semiaridez são mais acentuadas com um regime pluvial extremamente irregular ao longo do ano. Os máximos de chuvas, além de muito reduzido e variável, estão submetidos na maioria das vezes aos efeitos propagados pela Zona de Convergência Intertropical (ZCIT) representada pelas instabilidades meteorológicas oriundas do setor norte da Bahia.

O estado da Bahia possui cerca de mais de $320211 \mathrm{Km}^{2}$ do seu território inserido no Polígono das Secas abrangendo um grande contingente populacional, portanto a área submetida ao fenômeno das secas possui extrema representatividade ambiental e socioeconômica do ponto de vista espacial.

Os municípios integrantes do território de Identidade do São Francisco são caracterizados pelo elevado déficit hídrico anual, característica esta que se agrava no sentido de sul para norte em direção aos áreas limítrofes do estado.

Estudos realizados (CEI, 1991) informam que cerca de 75\% da área total do semiárido estão incluídas como de risco de seca alto. Nos $25 \%$ restantes, o risco é médio. A estiagem acontece, normalmente, com maior ou menor intensidade, em função das condições climáticas próprias da região semiárida. A seca se configura quando a estiagem se prolonga excessivamente, levando a população a uma situação crítica.

A preocupação com a escassez e a irregularidade espacial das chuvas no estado da Bahia e no nordeste brasileiro, tem sido uma constante em vários estudos realizados, e esta preocupação se acentua no que se refere ao fenômeno das secas. Aldaz (1971), em trabalho realizado sobre a caracterização pluvial do regime das chuvas no nordeste, analizam anomalias pluviais ocorridas ao longo do período 1914-1960 demonstrando que a ocorrência de anos anormais não é habitual. Predominam períodos significativos e extremos de seca, embora, sem o mesmo grau de frequência, ocorram, também extremos chuvosos.

A área escolhida para efeito de realização deste estudo do ponto de vista pluvial encontra-se inserida na isoieta anual inferior a $600 \mathrm{~mm}$, com duas estações bem marcadas: a seca e a chuvosa. O quadro 01 apresenta alguns aspectos climatológicos relacionados a alguns municípios do Território de Identidade Sertão do São Francisco.

A temperatura média anual varia em torno de 24 a $26{ }^{\circ} \mathrm{C}$, podendo as temperaturas 
máximas alcançam valores bem mais elevados, sobretudo nas áreas limítrofes no setor norte da região. As elevadas temperaturas o ano todo concorrem para uma tipologia climática denominada de megatérmica típica das latitudes tropicais. As amplitudes térmicas anuais são pouco relevantes quando comparadas com a amplitude térmica diária, o que vem a caracterizar uma forma típica do semiárido baiano.

Quadro 01 - Aspectos Climatológicos Gerais do Território de Identidade Sertão do São Francisco (BA)

\begin{tabular}{|c|c|c|c|c|c|c|c|c|}
\hline Espaço & $\begin{array}{c}\text { Alguns } \\
\text { Municípios }\end{array}$ & $\begin{array}{l}\text { Sazonalidade } \\
\text { das Chuvas }\end{array}$ & $\begin{array}{c}\text { Altura } \\
\text { Pluviome } \\
\text { tria } \\
\text { Anual } \\
\text { (mm) }\end{array}$ & $\begin{array}{l}\text { Trimestre } \\
\text { mais } \\
\text { crítico de } \\
\text { chuvas }\end{array}$ & $\begin{array}{c}\text { Duração } \\
\text { do } \\
\text { período } \\
\text { de seca }\end{array}$ & $\begin{array}{c}\text { Deficiência } \\
\text { Hídrica } \\
\text { (mm) }\end{array}$ & $\begin{array}{c}\text { Excedente } \\
\text { Hídrico } \\
\text { (mm) }\end{array}$ & $\begin{array}{c}\text { Tempe- } \\
\text { ratura } \\
\left({ }^{\circ} \mathrm{C}\right) \\
\text { Média } \\
\text { Anual }\end{array}$ \\
\hline 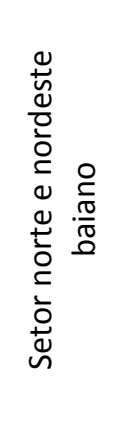 & $\begin{array}{c}\text { Pilão } \\
\text { Arcado } \\
\text { Sento Sé } \\
\text { Juazeiro } \\
\text { Remanso } \\
\text { Campo } \\
\text { Alegre de } \\
\text { Lourdes } \\
\text { Curaçá } \\
\text { Uauá }\end{array}$ & 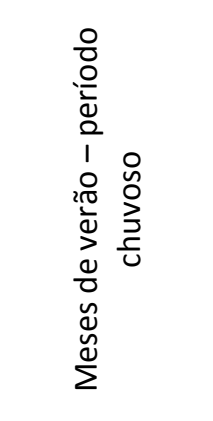 & $\begin{array}{l}\varepsilon \\
\varepsilon \\
\varnothing \\
\varnothing \\
\vee\end{array}$ & 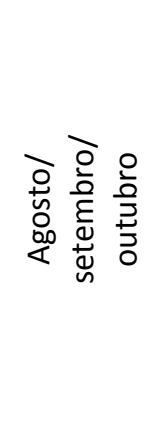 & 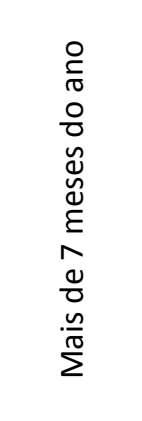 & $\begin{array}{l}\frac{n}{\pi} \\
\frac{n}{\partial} \\
\frac{1}{\sigma} \\
\varepsilon \\
\varepsilon \\
\delta \\
\varnothing \\
\varnothing \\
1 \\
\varnothing \\
\varnothing\end{array}$ & $\frac{O}{\stackrel{N}{N}}$ & 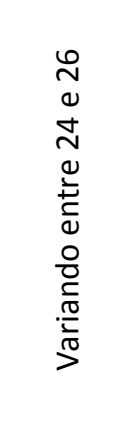 \\
\hline
\end{tabular}

Fonte: INMET (2010). Adaptado: Emanuel Reis de Jesus.

As chuvas por sua vez, se concentram num determinado período do ano, que é no verão e são originadas das influências propagadas pelas perturbações meteorológicas, oriundas do setor norte da região. O volume de chuvas anuais é inferior a $600 \mathrm{~mm}$, o que vem caracterizar a sua forte tendência a semiaridez acentuada. Face a essa irregularidade pluvial ao longo do ano, aliado ao escasso volume tem-se um quadro de deficiência hídrica elevado em todos os municípios inseridos no Território de Identidade Sertão do São Francisco.

\section{Aspectos agroclimatológicos regionais}

A abordagem geográfica do clima aplicada à agricultura consiste, acima de tudo, na possibilidade de se averiguar o grau de dependência entre o comportamento dos elementos e atributos climáticos e o desempenho das culturas agrícolas. Nenhuma outra atividade desenvolvida pelo homem é tão dependente do clima, quanto a agricultura, daí a importância da sua investigação interativa com os demais componentes do meio natural.

O método do balanço hídrico, em particular, consiste numa contabilização da quantidade da 
água no solo, ou seja, uma maneira de se mensurar o ganho e a perda de água no solo. No sertão nordestino, e mais particularmente, em todo o Território de Identidade do Sertão do São Francisco, as chuvas são extremamente reduzidas e irregulares do ponto de vista espacial.

Por outro lado, as temperaturas possuem maior homogeneidade ao longo do ano, prevalecendo as elevadas temperaturas médias anuais.

Para efeito de análise agroclimatológico, o método do Balanço Hídrico por Thorthwaite (1955) apud Ayoade (1981), representa em tratamento estatístico satisfatório para se avaliar as condições de abastecimento de água no solo, a retirada hídrica, deficiência hídrica dentre outros parâmetros de natureza edafológica regional.

O balanço hídrico de Thorthwaite (1948) apud Ayoade (1981) é também amplamente utilizado nas análise agroclimatológicas regionais, adotando-se preferencialmente a capacidade de campo de $125 \mathrm{~mm}$.

O referido método é operacionalizado com cerca de 11 variáveis, sendo as mais importantes para efeito contábil as temperaturas mensais e anuais, assim, como as chuvas, respectivamente, seguida pelos demais componentes tais como a evapotranspiração potencial a real dentre outras. Neste método as chuvas, ou seja, a precipitação pluviométrica $(P \mathrm{~mm}$ ) representam o ganho de água para o solo, enquanto que a evapotranspiração potencial (EP $\mathrm{mm}$ ) representa a perda de água pelo solo. $\mathrm{O}$ índice hídrico proposto pelo referido autor representa um indicador de grande definição das reais condições hídricas regionais.

O Território de Identidade Sertão do São Francisco é, acima de tudo, marcado por severas secas, onde a deficiência hídrica no solo alcança mais de seis meses ao longo do ano com grandes reflexos sobre a agricultura regional. As áreas mais críticas estão localizadas a nordeste da região, principalmente, nos setores limítrofes do estado da Bahia.

A ocorrência de solos rasos, mesmo por vezes inexistentes, com inúmeros afloramentos em forma de lajeados, a presença de uma cobertura de natural de aparência agressiva e de na natureza xerófila, concorre para a singularidade de uma paisagem cujo o clima exerce uma posição de vanguarda. Do ponto de vista climatológico, a área carece da existência de postos meteorológicos distribuídos por todos os municípios, o que dificulta na obtenção de informações detalhadas de cada município. Apenas dois municípios dispõe de dados 
climatológicos com longas séries de dados com mais de 30 anos de dados completos.

Os dados meteorológicos disponíveis em alguns municípios apresentam extremas falhas e irregularidades, são em sua maioria, dentre os existentes, dados pluviométricos mensais. Para efeito de investigação inicial foram selecionadas os municípios de Petrolina e Remanso, cujas temperaturas médias anuais são superiores a $26^{\circ} \mathrm{C}$ e o índice pluviométrico anual é de $609,8 \mathrm{~mm}$ e $696 \mathrm{~mm}$, respectivamente.

Os dados climatológicos que serviram de suporte para o estudo, foram fornecidos pelo Instituto Nacional de Meteorologia (INMET) e postos pluviométricos pertencentes a Secretaria de Recursos Hídricos do Estado da Bahia. As duas cidades acima mencionadas, revelaram que os dados de EP $(\mathrm{mm})$ suplantaram na maioria dos meses os valores de $\mathrm{P}(\mathrm{mm})$, revelando que a perda foi muito maior do que o ganho de água no solo, daí os elevados índices de deficiência hídrica anual na região, supracitados os $650 \mathrm{~mm}$ anuais.

Diante do quadro a seguir, tem-se uma situação peculiar no contexto do estado da Bahia com graves repercussões no cenário econômico e social da região e, mais particularmente, no plano da produção agrícola.

No quadro e gráfico 02 tem-se a média anual da precipitação mensal ( $\mathrm{mm}$ ) dos municípios da área de estudo, 2004 - ano que tem-se a imagens orbitais. 


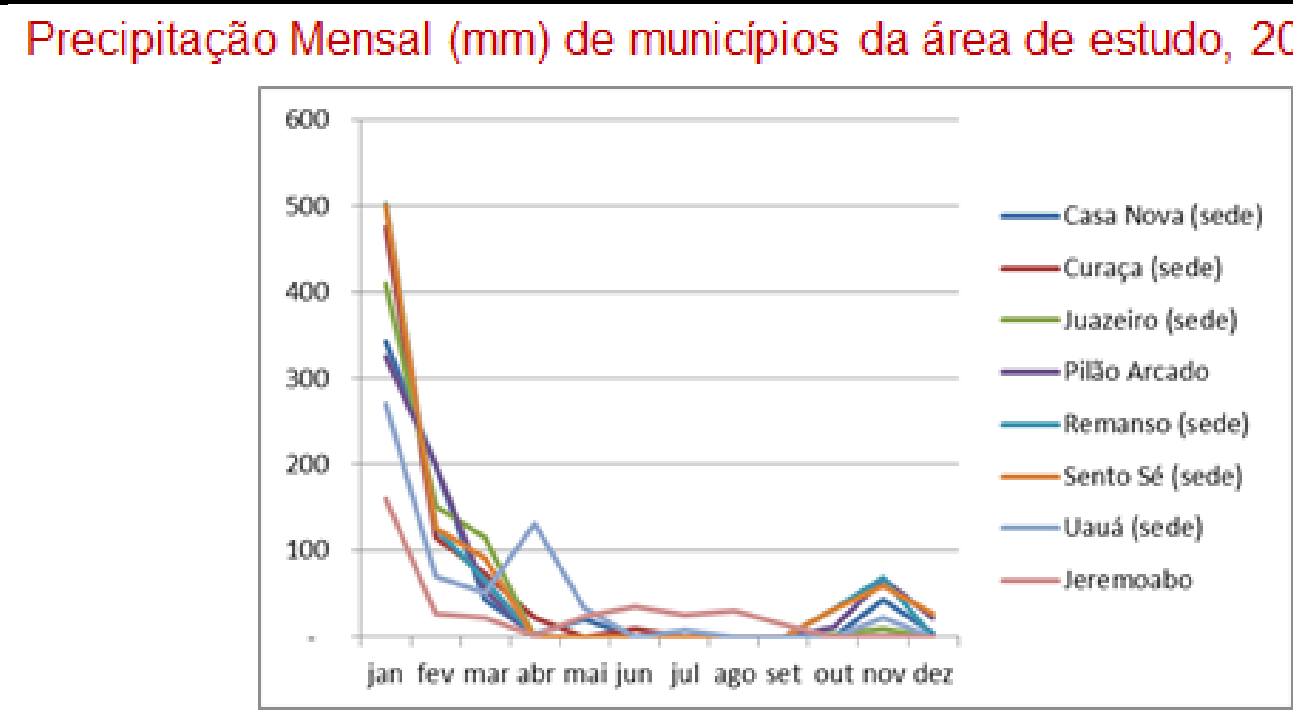

\begin{tabular}{|c|c|c|c|c|c|c|c|c|c|c|c|c|}
\hline Munićópios & jan & ter & mer & $a b r$ & mai & jun & jul & $\sec$ & set & out & nov & dez \\
\hline Case Nora (sede) & 3418 & 199,0 & 42,5 & 2,3 & 20,5 & 0,0 & 0,0 & 0,0 & 0,0 & 0,2 & 425 & 20 \\
\hline Curaca (sedel] & 4790 & 1149 & 72.5 & 22.5 & 0,0 & 10,0 & 0,0 & 0,0 & 0,0 & 0,0 & 0,0 & $0 \rho$ \\
\hline Juaneio (vede) & $409 / 4$ & 152,6 & 114,4 & 0,0 & 0,0 & 0,0 & 0,0 & 0,0 & 0,0 & 3,6 & 10,0 & 0,4 \\
\hline Pilíso Aredo & 3243 & 200,0 & $\$ 40$ & 0,0 & 0,0 & 0,0 & 0,0 & 0,0 & 0,0 & 10,7 & 65,5 & 22,3 \\
\hline Remenvo (rede) & 302.5 & 125,8 & 64.8 & 0,0 & 0,0 & 0,0 & 0,0 & 0,0 & 0,0 & 32,2 & 673 & 0,0 \\
\hline Sento Sé (ende) & 5010 & 125,4 & 90,4 & 0,0 & 0,0 & 0,0 & 0,0 & 0,0 & 0,0 & 32,0 & 99,0 & 27,2 \\
\hline Usué (yede) & 2710 & 70,6 & 90,5 & 131,6 & 32,5 & 0,0 & 7,2 & 0,0 & 0,0 & 0,0 & 225 & 0,0 \\
\hline Jeremo:bo & 1601 & 27,7 & 21.8 & 0,5 & 242 & 35,5 & 23,5 & 30,2 & 14,1 & 0,0 & 1.0 & 0,3 \\
\hline
\end{tabular}

FONTE: INMET, 2004

\section{As imagens Orbitais SPOT 4 - Vegetation}

O Geoprocessamento nos últimos anos tem se tornado um grande aliado nos estudos ambientais e no monitoramento da produção agrícola. Sendo assim, neste trabalho através do software ENVI (que é uma ferramenta de Geoprocessamento) também com a ajuda do ArcGis foi possível processar e manipular as imagens do satélite SPOT4-Vegetation, que por sua vez, forneceram informações fundamentais quanto às taxas de umidade do solo, podendo, portanto, identificar os meses do ano de 2004 que viveram momentos de escassez hídrica e como esta escassez poderia afetar na agricultura conforme a interpretação das imagens e do cálculo do NDVI.

Verifica-se, portanto, que o Sertão do São Francisco é de fato uma área que sofre déficit hídrico e que isso repercute no âmbito socioeconômico da população local. Em locais com evidência de seca, os municípios que compõem este território de identidade, um dos métodos utilizados para diminuir tais efeitos é a doção de técnicas de irrigação, tendo como finalidade atender as necessidades hídricas dos cultivos, de modo a minimizar os efeitos 
danosos da seca. Porém, apesar dos recentes avanços científicos, o clima é ainda a variável mais importante no processo de desenvolvimento da prática agrícola. Os parâmetros climáticos exercem influência sobre todos os estágios da cadeia produtiva, incluindo a preparação do solo, semeadura, crescimento dos cultivos agrícolas, colheita, armazenagem, transporte e comercialização. Pode-se dizer que os elementos climáticos, tais como a radiação solar, temperatura e umidade afetam diretamente a produção agrícola e que no semi-árido baiano, isto é, intensificado pelas especificidades das características físicas do local, assim como o solo, relevo, distribuição das chuvas, recursos hídricos e vegetação natural.

Para a execução da pesquisa foram necessários a manipulação, processamento e interpretação das imagens orbitais do satélite SPOT 4 - Vegetation e LANDSAT 5 trabalhadas a partir dos softwares ENVI e ArcGis, como já foi dito. Coleta de dados da Produção Agrícola Municipal (PAM/IBGE) disponibilizados na internet pelo site do próprio IBGE. Coleta de dados referentes à distribuição de verbas do PRONAF também acessíveis na internet.

Em relação às imagens orbitais, o satélite SPOT 4 leva a bordo um sensor com o objetivo de monitorar diariamente a vegetação em escala planetária. Foi a partir deste sensor a geração de produtos como o Índice de Vegetação da Diferença Normalizada (NDVI) que é utilizado na estimativa da produção agrícola com relações à precipitação e temperatura. Sendo assim, tornou-se de fundamental importância a aplicação deste instrumento para detectar a distribuição da cobertura vegetal verde na superfície e sua evolução no período analisado (2004-2006).

O NDVI define-se pela seguinte cálculo:

$$
N D V I=(R 2-R 1) /(R 2+R 1)
$$

Seu produto é obtido a partir de combinações entre as bandas do vermelho e infravermelho próximo e a partir de seus valores se identificam os padrões de seca. Os valores oscilam entre -1 e +1 e permitem identificar a presença ou ausência de vegetação verde na superfície e caracterizar a sua distribuição espacial bem como a evolução de seu estado ao longo do tempo, a qual é determinada pelas variações das condições climáticas predominantes. 
Trabalhou-se com um conjunto de 36 imagens, correspondentes a um grupo de 3 imagens em cada mês do ano de 2004. A coleta de cada uma destas imagens no site http://free.vgt.vito.be/, o que tomou um considerável tempo no decorrer do trabalho. A imagem era da América do Sul, sendo necessário recortar a área de interesse para cada uma delas por meio do software ENVI.

Fez-se o de 12 imagens, uma imagem referente a cada mês do ano de 2004. O próximo passo foi o destacar as diferenças entre os pixels com o Índice de Vegetação por Diferença Normalizada (NDVI) mais diferenciados e analisá-los juntamente com os outros dados da pesquisa. (Figuras 6 e 7).

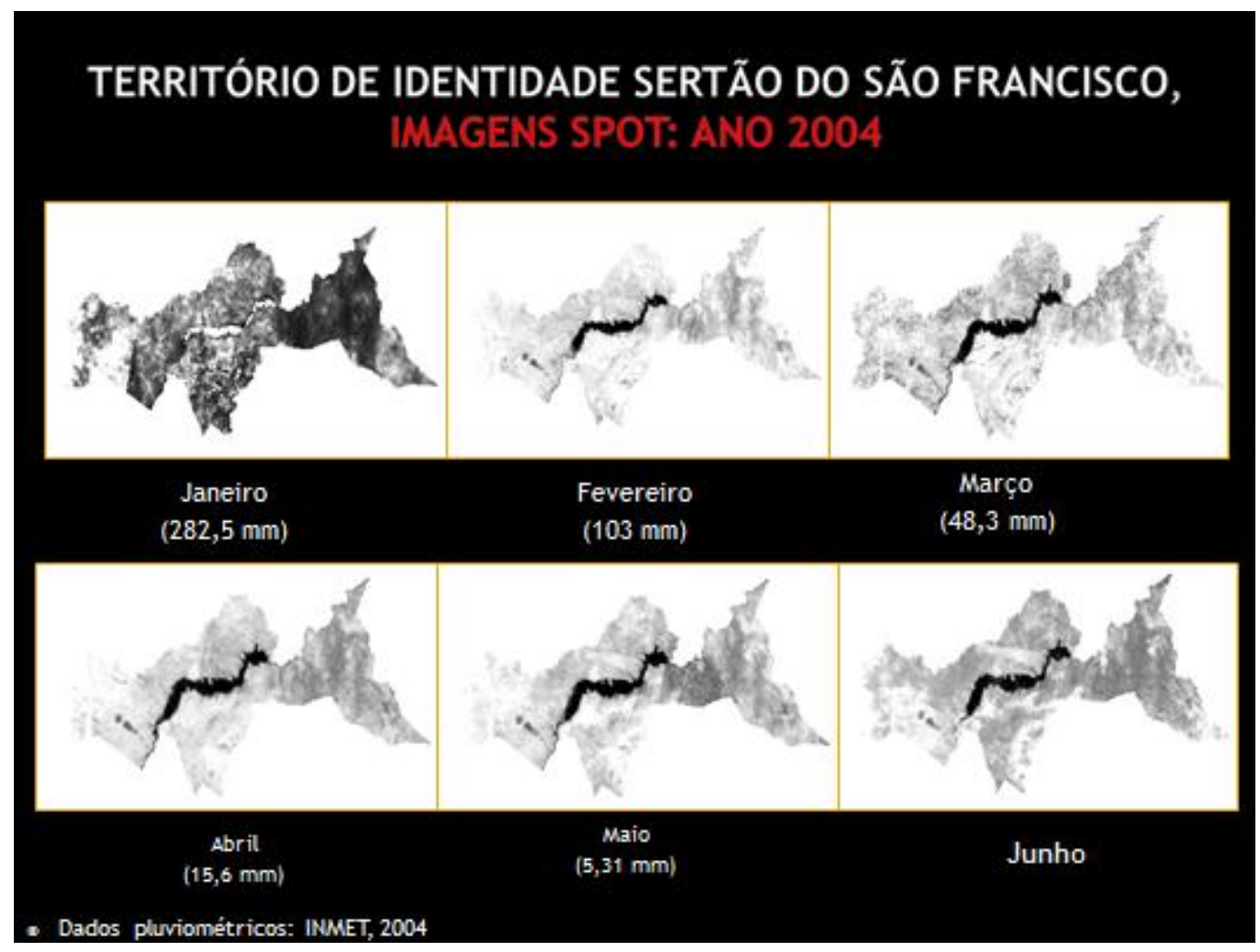

Fonte: ENVI, 2009.

Figura 6: Imagens SPOT 4 - VGT para o primeiro semestre de 2004

Em cada uma das imagens aparecem tonalidades diferentes onde manchas claras (ou brancas) apresentam valores altos de NDVI, ou seja, não estão sofrendo naquele momento de falta de água no solo. Destaca-se que o valor do NDVI é automaticamente dado pelo sensor Vegetation no SPOT 4. O valor do NDVI informando a taxa mais elevada de umidade do solo é de dezembro de 2004. 


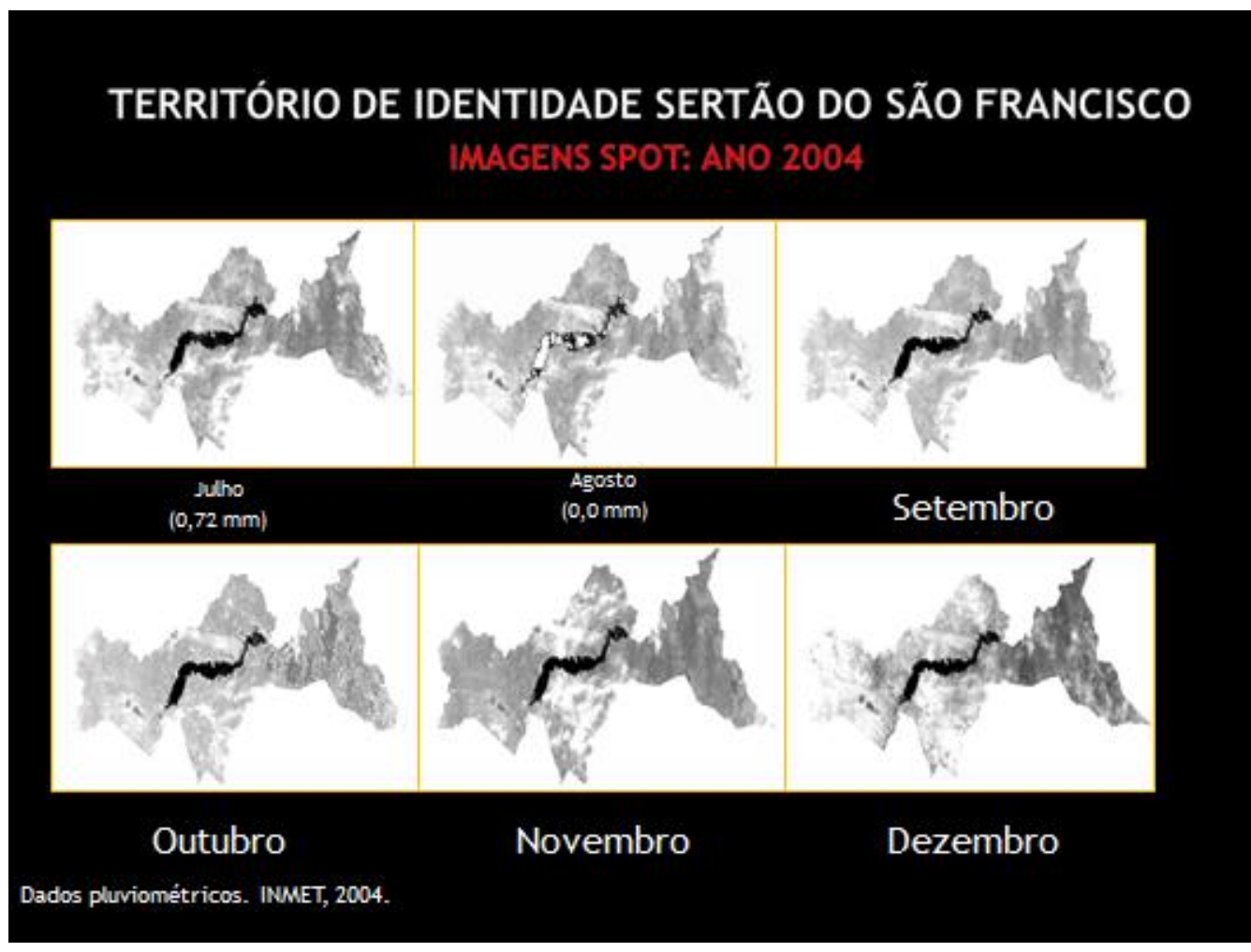

Fonte: ENVI, 2009.

Figura 7: Imagens SPOT 4 - VGT para o segundo semestre de 2004.

Em seguida as imagens foram interpretadas conforme as tonalidades de cinza. Neste aspecto, tonalidade de cinza mais escuro é sinal de escassez hídrica no solo, portanto, vegetação seca, e tonalidade mais clara de cinza refere-se a um teor de umidade mais significativo no solo, ou seja, que a taxa de água aí presente é suficiente para manter a vegetação verde.

Conforme esta interpretação pode-se dizer que a imagem do mês de março de 2004, que aparece em tonalidade clara de cinza, nos fornece a informação de que o solo do Sertão do São Francisco, até então, não apresentava déficit hídrico. Os meses abril, maio e junho também apresentam tonalidades de cinza semelhantes. Imagem referente ao mês de março de 2004.

Para a imagem correspondente ao mês de setembro do mesmo ano, por apresentar tonalidade mais escura de cinza, pode-se afirmar, portanto, que a área de estudo em determinados pontos, possivelmente, apresentava taxas negativas de umidade do solo o que não mantém a vegetação verde. Imagem referente ao mês de setembro. 
Entretanto, deve-se lembrar que por ser uma área produtora de frutas e com várias áreas irrigadas encontram-se manchas esbranquiçadas durante todo o ano, o que irá ser discutido mais à frente neste relatório.

Com o cruzamento das imagens de meses diferentes pôde-se destacar as diferenças. (Figura 8).

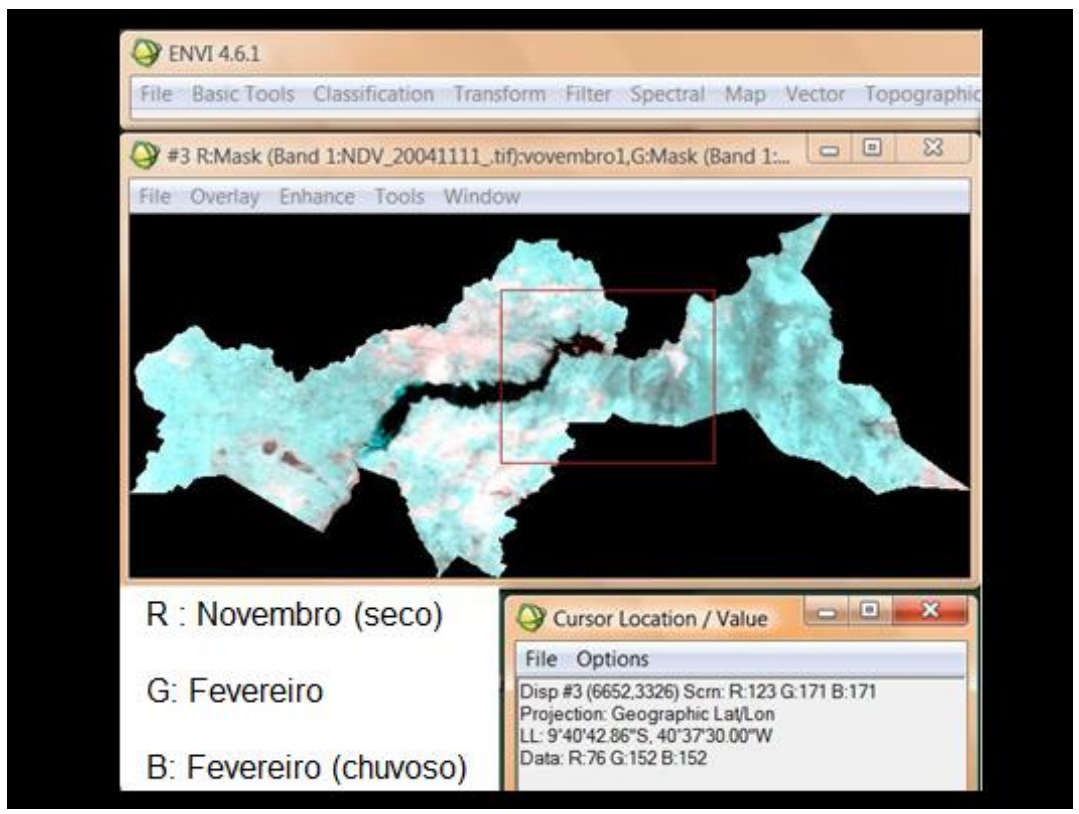

Fonte: Envi, 2010.

Figura 8: Sobreposição de duas imagens com NDVI diferentes. Nota-se que o R (que representa o mês de novembro - seco) tem valor 76, enquanto o G e o B (que representam Fevereiro) tem valor 152.

Após recorte e processamento das imagens orbitais do satélite Spot-4 Vegetation efetuou-se

o levantamento da produção agrícola no Território de Identidade Sertão do São Francisco, fazendo, sobretudo, a distinção entre os municípios mais representativos em determinada atividade agrícola e os não representativos no conjunto da região. Através dos dados obtidos no IBGE, PAM e PRONAF foram analisadas as transformações ocorridas na prática agrícola nos decorrentes anos de 2004 a 2006, que serão apresentados mais a frente neste relatório.

Questões sócio-econômicas e de gestão pública no território de identidade sertão do São Francisco (BA) 
Devido à sua tipologia climática caracterizada, principalmente, pela deficiência hídrica, percebeu-se a tamanha vulnerabilidade ambiental do Sertão do São Francisco, um dos vinte e seis territórios de identidade da Bahia, que se encontra totalmente localizado no semiárido nordestino. Sendo assim, este território de grande importância agrícola para o estado baiano, representado especialmente pelo município de Juazeiro como um pólo de desenvolvimento para a região.

Elaborou-se a Taxa de Crescimento Populacional total, urbana e rural dos dez municípios componentes da área de estudo (Tabelas 1) (Campo Alegre de Lourdes, Canudos, Casa Nova, Curaçá, Juazeiro, Pilão Arcado, Remanso, Sento Sé, Sobradinho e Uauá) além de ter sido feito também um levantamento dos dados socioeconômicos de todos estes municípios. Através dos primeiros resultados alcançados foi possível preparar uma apresentação, no ano de 2009, para o I Simpósio Sobre Cidades Médias e Pequenas na Bahia sediado no Instituto de Geociências da Universidade Federal da Bahia, o trabalho apresentado teve como título Sertão do São Francisco: mesmo Território e diferentes identidades, 1970 a 2007.

Verifica-se, portanto, que o Sertão do São Francisco é de fato uma área que sofre déficit hídrico e que isso repercute no âmbito socioeconômico da população local. Em locais com evidência de seca, os municípios que compõem este território de identidade, um dos métodos utilizados para diminuir tais efeitos é a doção de técnicas de irrigação, tendo como finalidade atender as necessidades hídricas dos cultivos, de modo a minimizar os efeitos danosos da seca. Porém, apesar dos recentes avanços científicos, o clima é ainda a variável mais importante no processo de desenvolvimento da prática agrícola.

Tabela 1. Taxa de Crescimento Populacional urbana e rural (\%), 1970 a 2000.

\begin{tabular}{|c|c|c|}
\hline Municípios & T C Urbana (\%) & T C Rural (\%) \\
\hline Campo Alegre de Lourdes & 275,3 & 40,2 \\
\hline Canudos & - & - \\
\hline Casa Nova & 397,4 & 20,8 \\
\hline Curaçá & 279,2 & 82,9 \\
\hline Juazeiro & 241 & 2,59 \\
\hline Pilão Arcado & 210,6 & $-7,73$ \\
\hline Remanso & 187,2 & $-7,11$ \\
\hline Sento Sé & 184,9 & - \\
\hline Sobradinho & - & 12 \\
\hline Uauá & 260,1 & \\
\hline
\end{tabular}

Fonte: IBGE, 1970 a 2000 
Os parâmetros climáticos exercem influência sobre todos os estágios da cadeia produtiva, incluindo a preparação do solo, semeadura, crescimento dos cultivos agrícolas, colheita, armazenagem, transporte e comercialização.

Pode-se dizer que os elementos climáticos, tais como a radiação solar, temperatura e umidade afetam diretamente a produção agrícola e que no semiárido baiano, isto é, intensificado pelas especificidades das características físicas do local, assim como o solo, relevo, distribuição das chuvas, recursos hídricos e vegetação natural.

Quanto a área plantada e a quantidade produzida, seguem os totais da área de estudo. (Tabela 2).

Tabela 2. Área plantada (ha) e quantidade produzida (lavoura permanente e temporária) referente aos municípios componentes do Território de Identidade do Sertão do São Francisco (BA), triênio 2004 - 2006.

\begin{tabular}{|c|c|c|c|c|c|c|}
\hline Municípios & $\begin{array}{c}\text { Área (ha) } \\
2004\end{array}$ & $\begin{array}{c}\text { Quantidade } \\
\text { (ton) 2004 }\end{array}$ & $\begin{array}{c}\text { Área (ha) } \\
2005\end{array}$ & $\begin{array}{c}\text { Quantidade } \\
\text { (ton) 2005 }\end{array}$ & $\begin{array}{c}\text { Área (ha) } \\
2006\end{array}$ & $\begin{array}{c}\text { Quantidade } \\
\text { (ton) 2006 }\end{array}$ \\
\hline C. A. de Lourdes & 14121 & 42262 & 13252 & 44873 & 10750 & 32380 \\
\hline Canudos & 3291 & 15427 & 2160 & 11056 & 2513 & 17263 \\
\hline Casa Nova & 5148 & 46132 & 5968 & 75100 & 9762 & 122347 \\
\hline Curaçá & 5695 & 59949 & 4408 & 72444 & 5877 & 100370 \\
\hline Juazeiro & 28704 & 1363333 & 32947 & 1821327 & 38979 & 1735402 \\
\hline Pilão Arcado & 12469 & - & 12519 & - & 9277 & - \\
\hline Remanso & 20 & 80 & 9310 & - & 13240 & - \\
\hline Sento Sé & 5270 & 69666 & 4730 & 67315 & 6451 & 84831 \\
\hline Sobradinho & 583 & 4683 & 613 & 6366 & 728 & 7931 \\
\hline Uauá & 3455 & 5000 & 2885 & 6872 & 3428 & 5134 \\
\hline
\end{tabular}

Fonte: IBGE - Produção Agrícola Municipal, 2004, 2005 e 2006.

Perante esta situação, pode-se deduzir que Canudos, Remanso, Sobradinho e Uauá estão mais sujeitos aos episódios meteorológicos, pois sua atividade agrícola é composta na maioria por pequenos produtores e também por criadores de caprinos.

Enquanto que, em destaque, estão os produtores de Juazeiro e Casa Nova, onde estão localizados os principais perímetros irrigados em funcionamento na data das imagens e consequentemente os maiores produtores de frutas e cana-de-açúcar. (Tabela 3).

De modo geral, os principais cultivos agrícolas da área de estudo são: banana, batata doce, cana-de-açúcar, cebola, coco da baía, feijão, goiaba, mamão, mamona, mandioca, manga, maracujá, melancia, milho, sisal e uva. Sendo que as frutas tem, quase certo, como destino o mercado internacional. Por isso, uma das razões de existir o Aeroporto em Petrolina (PE). 
Tabela 3. Projetos de Irrigação em operação em 2003.

\begin{tabular}{|c|c|c|}
\hline Municípios & Projeto & Área irrigada/ irrigável (ha) \\
\hline Curaçá & Árvore/Mosquito & 20 \\
\hline Sobradinho & Chapadinha & 4350 \\
\hline Juazeiro & Curaçá & 913 \\
\hline Sento Sé & Itapera & 38 \\
\hline Juazeiro & Jacaré & 420 \\
\hline Juazeiro & Mandacaru & 4293 \\
\hline Juazeiro & Maniçoba & 240 \\
\hline Sento Sé & Pascoal Limoeiro & 1115 \\
\hline Casa Nova & Senador Nilo Coelho & 260 \\
\hline Sobradinho & Tataui & 11240 \\
\hline Juazeiro & Tourão & 2091 \\
\hline Canudos & Vaza Barris & \\
\hline
\end{tabular}

Fonte: SEI, 2004.

\section{Estrutura Fundiária e Produção Agrícola}

Análise da estrutura fundiária que compõem o Território de Identidade Sertão do São Francisco foi melhor estruturado por municípios em separado, a seguir:

\section{Campo Alegre de Lourdes}

Os primeiros dados do município de Campo Alegre de Lourdes referentes à estrutura fundiária são do ano de 1970. Para este ano, aparece distintamente a predominância da pequena propriedade com menos de 50 hectares que representando $89,5 \%$ do total de estabelecimentos e ocupavam uma área correspondente a $44 \%$ do total municipal.

As grandes propriedades, por outro lado, não aparecem em grande número, pois representam apenas $4,6 \%$ dos estabelecimentos. Mas elas ocupam $41 \%$ da área total municipal o que denota, para o referido ano, uma concentração fundiária de 0,6 no índice de Gini. Essa concentração foi ainda maior nos anos de 1985 quando o índice de Gini teve seu ápice com 0,84 , resultado da má distribuição das terras no município onde apenas $1,7 \%$ dos proprietários detinham $41 \%$ da área total. No decorrer dos anos seguintes a tendência da 
grande concentração de terras permaneceu sendo que apenas dois proprietários $(0,05 \%$ do total de estabelecimentos) possuíam 23\% do total da área do município de Campo Alegre de Lourdes.

Em relação a produção de cultivos temporários, entre os municípios estudados Campo Alegre de Lourdes aparece como maior produtor de mandioca e milho, mas o município é também o segundo (junto com Pilão Arcado) maior produtor de feijão. Esses produtos são tipicamente características de pequena propriedade.

A produção de mel de abelha deste município aparece $10^{a}$ posição no estado da Bahia no ano de 2006, com uma produção de 223 mil quilos.

\section{Juazeiro}

Na análise da estrutura fundiária do município de Juazeiro é interessante destacar que, de fato, o índice de Gini aponta sempre para a concentração das terras no município. Além disso, a partir de 1940 percebe-se a ocorrência de uma ocilação entre 0,6 e 0,86 com destaque para o ano de 1985 quando o município apresentou sua maior concentração.

Diferente de muitos outros municípios brasileiros e mesmo baianos, Juazeiro apresenta dados de sua estrutura fundiária ainda nos anos de 1920 quando apresentava extrema concentração fundiária tendo no índice de Gini 0,93. Nesse ano, os dados do IBGE apontam que apenas $5 \%$ dos proprietários concentravam cerca de $78 \%$ da área total do município, são propriedades que detém entre 5.000 e 25.000 hectares.

Já para os anos de 1940 e 1960 ocorre uma pequena redistribuição das áreas e já não aparecem propriedades com mais de 500 hectares e o maior número de propriedades serão de minifúndios e pequenas propriedades sendo que mais de $95 \%$ do total possuirão menos de 50hectares.

Contudo, em 1996 os dados apontam para uma nova e grande concentração de terras em propriedades com mais de mil hectares. Nesse ano, 0,6\% das propriedades (28 estabelecimentos) possuíam $45 \%$ do total da área do município de Juazeiro.

O município de Juazeiro representava no ano de 2006 26\% da produção de cana-de-açúcar do estado da Bahia, com 1.600 mil toneladas em área de 16,6 mil hectares. 
A pesar de o município de Juazeiro produzir diversos tipos de frutas (coco, limão, mamão, manga, maracujá, melancia, melão e uva), há uma concentração expressiva em algumas específicas. Nesse sentido, o município é responsável por cerca de 70\% (436 mil/t.) da produção de manga, 19\% (46 mil/t.) da produção de melancia, 95\% (45 mil/t.) da produção de melão e 98\% (114 mil/t.) da produção de uvas do estado da Bahia. A cana-de-açúcar produzida no município refere-se principalmente a prudução de uma única empresa, a Agrovale que, em 2002, segundo dados da Embrapa/IBGE, colheu 13.528 hectaresdo vegetal. Já na produção animal, o município aparece com 3,7 \% da produção estadual de eqüinos (SEI/ e IBGE).

\section{Curaçá}

Este município apresentou nos anos de 1940, uma boa distribuição de suas terras quando mais de $95 \%$ das propriedades possuíam menos de 50 ha. O que chama a atenção é a grande presença de minifúndios, $83 \%$ dos estabelecimentos possuíam menos de 5 ha e ocupavam 53\% da área total do município que era de 8160ha.

Contudo, ao adentrar a década de 1960 ocorrem consideráveis mudanças na estrutura fundiária do referido município. Diminui drasticamente os minifúndios com menos de 5ha, caindo para $12 \%$ de propriedades nessa situação ocupando apenas $1,2 \%$ do total de terras.

Já as propriedades que possuíam entre 10 e 50, consideradas pequenas, apresentam crescente proporção, representando $77 \%$ e ocupando $50 \%$ da área total. Porém, a concentração efetiva começa aparecer de modo muito acentuado. Nesse ano, uma propriedade apenas de 8.700 hectares concentrava $12,4 \%$ da área total do município.

Nos anos de 1980 a concentração das terras apresenta-se fortemente nas propriedades acima de 500 ha, sendo que estas representam apenas $1,4 \%$ do total, mas que detêm $53 \%$ da área total do município.

Para o ano de 1996 a concentração das terras do município de Curaçá continua aumentando entre os proprietários com mais de 500ha e até $10 \mathrm{mil}$ ha. Essas propriedades aparecem ocupando uma área superior a $60 \%$ do total municipal, sendo que apenas 5 propriedades possuíam 19.500 hectares. 
O município de Curaçá produz $23 \%$ de todo amendoim baiano e de $13 \%$ da produção estadual de goiaba, com 2,1 mil toneladas no ano de 2006.

\section{Casa Nova}

A estrutura fundiária do município de Casa Nova apresenta, desde o início dos dados censitários, concentração das terras sendo que o índice de Gini variou entre 0,63 e 0,77 no período de 1950 a 1996.

O que chama a atenção para o ano de 1950 é a presença de um grande latifúndio contendo 14 mil ha o que representava $9,6 \%$ do total das terras do município. Fora isso, mais de $80 \%$ das propriedades possuíam menos de 50 ha.

No ano de 1960 continua a grande proporção de propriedades (mais de 90\%) com menos de 50ha. Por outro lado, duas grandes propriedades com mais de 7 mil ha detêm $14 \%$ das terras do município o que agrava em 1970 quando apenas três propriedades passam a ter o domínio de $26 \%$ das terras. Já para o ano de 1980 a novidade é a concentração de terras entre proprietários de 100 e 1000ha que detinham 19\% do total da área, proporção essa que se eleva para 39\% no ano de 1996.

Além disso, nesse mesmo ano aparece a concentração de terras em duas propriedades, uma com 3.500ha e outra com 7150ha. De modo geral percebe-se que nos últimos anos do censo, a concentração de terras foi agravada nesse município.

Este município aparece de forma significativa na produção de cebola no estado da Bahia. Sua produção de 187 mil toneladas no ano de 2006 correspondeu a 75\% do total de cebola produzida no estado.

Neste município é notável ainda a criação de animais que aparecem em diversidade. Em relação a produção estadual, para o ano de 2006, Casa Nova representou cerca de $12 \%$ da produção de asnos, com 37 mil cabeças e 10,4\% da produção de suínos, com 207 mil animais, como rebanhos mais expressivos.

No entanto, o município também aparece como produtor de ovos de codorna e de galinha, representando 6 e 1\%, respectivamente, do total da produção da Bahia.

\section{Canudos}


Os dados da estrutura fundiária de Canudos são do ano de 1996.

Para esse ano 93 \% das propriedades do município possuíam menos de 50 hectares, sendo dessas, 176 com menos de um hectare. Salienta-se que o agravante está em que essas propriedades detinham apenas $12,9 \%$ do total da área do município.

No outro extremo aparecem 4 propriedades ocupando 42454 hectares o que corresponde a 34\% da área total do município de Canudos.

\section{Remanso}

No ano de 1940, cerca da 94\% das propriedades do município de Remanso possuíam menos do que 50 ha em uma ocupando cerca de $65 \%$ do total da área do município.

Por outro lado, as propriedades com mais de 50ha até 200 ha que representavam cerca de $6 \%$ possuíam $35 \%$ do total da área que naquele ano era de 9.751 hectares.

O índice de Gini para esse ano era de 0,55, caracterizando uma relativa boa distribuição das terras no município. O índice de Gini aponta para o ano de 1970 uma grande concentração das terras no município de Remanso, chegando a 0,94, sendo o mais elevado de toda série histórica dos municípios envolvidos nesse projeto, ou seja, sertão do São Francisco. Apenas onze estabelecimentos que representavam $0,33 \%$ possuíam mais que 5 mil hectares cada e representavam mais de $46 \%$ do total da área do município.

O índice diminui um pouco no ano de 1980 e 1996 sendo, 0,84 e 0,77 respectivamente. Para 1996 permaneciam 6 propriedades $(0,14 \%)$ com mais de dois mil hectares ocupando mais de $16 \%$ do total da área municipal. Por outro lado $40 \%$ das propriedades possuíam menos de 50 ha e ocupavam cerca de $25 \%$ do total do município.

Este município produz significativa produção de caprinos e ovinos da Bahia. No ano de 2006, Remanso apresentou $49 \%$ da produção do rebanho de caprinos e $30 \%$ do rebanho de ovinos do estado. Já com produção menos significativa aparece a produção de bovinos de corte e de leite.

\section{Uauá}


Para o município há uma constante crescente no índice de Gini passando de 0,54 em 1960 mais de $90 \%$ dos estabelecimentos possuíam até 50 hectares e ocupavam cerca de $90 \%$ da área do município.

Índice de Gini 0,76 em 1970 - a predominância continua entre propriedades com menos de 50 ha, porém com cerca de $30 \%$ da área. A grande propriedade (apenas 16) mais de 500ha que representa $1,3 \%$ do total passa a concentrar cerca de $30 \%$ da área.

Índice de Gini 0,80 em 1980 - apenas 23 propriedades (2\%) com 500 até 10 mil ha possuíam cerca de $30 \%$ do total da área no município enquanto cerca de $80 \%$ das propriedades (com menos de 50 ha) ocupavam cerca de $24 \%$ das terras.

Índice de Gini 0,75 em 1996 - a situação muda um pouco nesse ano em relação as grandes propriedades, desaparecem aquelas com mais de 2 mil hectares. As propriedades com mais de 500 ha $(0,49 \%)$ possuíam $15 \%$ do total da área municipal.

\section{Pilão Arcado}

O município apresenta uma concentração de suas terras principalmente após a década de 1970 quando o índice de Gini apresenta uma gradativa elevação.

No ano de 1960 o índice era de 0,43 e 62\% dos estabelecimentos apresentavam entre 20 e 100ha e ocupavam uma área correspondente a $66 \%$ do total municipal.

Contudo, na década seguinte, apenas 4 propriedades deterão $15 \%$ do total da área do município, acrescendo, desse modo a concentração da propriedade privada da terra e o índice de Gini é elevado para 0,66.

Em 1980, 90\% das propriedades do município são minifúndios (menos de 10ha) e ocupam cerca de 32 \% do total da área. No outro extremo, 16 propriedades detêm $18 \%$ do total das terras fazendo elevar ainda mais o índice de Gini para 0,70.

No ano de 1996 a agravante é a ocorrência de 2 latifúndios ocupando 32 mil hectares. Eles representam apenas $0,04 \%$ das propriedades, mas ocupam 35\% do total do município. Esse dado certamente contribui para acrescer ainda mais o índice de Gini, 0,77.

\section{Sento Sé}


A estrutura fundiária desse município acompanha o que ocorre na maioria dos municípios do território Sertão do São Francisco, concentração de terras com índice de Gini elevado, principalmente a partir de 1960 quando passa de 0,62 para 0,82 em 1970. O índice cai um pouco em 1980 para 0,72 e volta a elevar-se em 1996 para 0,82.

Nesse período a característica fundamental é a presença constante de grande quantidade de minifúndios com menos de 10 ha representando entre 50 e $94 \%$ do total das propriedades do município, mas ocupando pouca área do município, cerca de $23 \%$.

Por outro lado, em 1970, temos o exemplo de uma propriedade que detinha 12 mil hectares, representando $33 \%$ área total.

\section{Sobradinho}

Por ter sido fundado no ano de 1989, Sobradinho só apresenta dados de sua estrutura fundiária para o ano de 1996 apresentando uma concentração das terras bastante elevada com índice de Gini apontando 0,88.

Cerca de $55 \%$ das propriedades são minifúndios com menos de 10 hectares e ocupam cerca de $3 \%$ do total do município.

Por outro lado, sete propriedades (cerca de $3 \%$ ) possuem cerca de $63 \%$ do total da área. Destes, um proprietário possui 10 mil hectares representando $29 \%$ do total da área.

A desigualdade na distribuição das terras no território de identidade do Sertão do São Francisco é presença constante em todo processo histórico, polarizando as pequenas propriedades e, principalmente os minifúndios por um lado e, por outro lado, os grandes latifúndios.

Segundo dados da CDA, INCRA e IBGE (2008), 55,10\% das terras da Bahia são devolutas, isto é, terras públicas que não estão registradas em nome do Estado. No Território Sertão do São Francisco total (6.174.600ha) e 78,12\% (4.823.663 ha) terras são devolutas; apenas 21,88 \% (1.350.937 ha) estão legalizadas ${ }^{14}$.

\section{Programa nacional de fortalecimento da agricultura familiar - pronaf}

\footnotetext{
14 “legalizados" (propriedade privada, propriedade do Estado da Bahia ou da União).
} 
Nos sete anos analisados (2000 a 2006) de implantação do Pronaf (Programa Nacional de Fortalecimento da Agricultura Familiar) nos municípios do território Sertão do São Francisco, percebe-se que alguns municípios foram mais constantemente beneficiados pelo programa, conforme a tabela abaixo. (Tabela 4).

Tabela 4 - Situação do PRONAF, 2000/ 2006.

\begin{tabular}{|c|c|c|c|c|c|c|c|c|}
\hline \multicolumn{9}{|c|}{$\begin{array}{l}\text { Número de contratos do Pronaf por município (os três com maior n. de contratos) e porcentagem do total no } \\
\text { Território de Identidade Sertão do São Francisco, 2000-2006. }\end{array}$} \\
\hline $\begin{array}{l}\text { Municípios } \\
\text { com maior } \mathrm{n} \text {. } \\
\text { contratos }\end{array}$ & $\begin{array}{c}2000 \\
(\%)\end{array}$ & $\begin{array}{c}2001 \\
(\%)\end{array}$ & $\begin{array}{c}2002 \\
(\%)\end{array}$ & $\begin{array}{c}2003 \\
(\%)\end{array}$ & $\begin{array}{c}2004 \\
(\%)\end{array}$ & $\begin{array}{c}2005 \\
(\%)\end{array}$ & $\begin{array}{c}2006 \\
(\%)\end{array}$ & $\begin{array}{l}\text { Total de } \\
\text { contratos p/ } \\
\text { município }\end{array}$ \\
\hline Casa Nova & $\begin{array}{c}53 \\
(4,87)\end{array}$ & $\begin{array}{c}624 \\
(41,85)\end{array}$ & $\begin{array}{c}2.189 \\
(60,24)\end{array}$ & $\begin{array}{c}1.296 \\
(63,13)\end{array}$ & $\begin{array}{c}527 \\
(18,94)\end{array}$ & $\begin{array}{c}685 \\
(10,99)\end{array}$ & $\begin{array}{c}1.089 \\
(16,34)\end{array}$ & 6.463 \\
\hline Curaçá & $\begin{array}{c}8 \\
(0,74) \\
\end{array}$ & $\begin{array}{c}151 \\
(10,13) \\
\end{array}$ & $\begin{array}{c}208 \\
(5,72) \\
\end{array}$ & $\begin{array}{c}154 \\
(7,50) \\
\end{array}$ & $\begin{array}{c}1.777 \\
(63,87) \\
\end{array}$ & $\begin{array}{c}1.685 \\
(27,03) \\
\end{array}$ & $\begin{array}{c}2.473 \\
(37,10) \\
\end{array}$ & 6.456 \\
\hline Juazeiro & $\begin{array}{c}255 \\
(23,44)\end{array}$ & $\begin{array}{c}405 \\
(27,16)\end{array}$ & $\begin{array}{c}383 \\
(10,54)\end{array}$ & $\begin{array}{c}125 \\
(6,09)\end{array}$ & $\begin{array}{c}400 \\
(14,38)\end{array}$ & $\begin{array}{c}1.747 \\
(28,02)\end{array}$ & $\begin{array}{c}1.249 \\
(18,74)\end{array}$ & 4.564 \\
\hline \multicolumn{9}{|c|}{$\begin{array}{c}\text { Fonte: Elaborado por Uilliam Lima e Noeli Pertile, adaptado de GeografAR; MDA/Pronaf - Ministério do } \\
\text { Desenvolvimento Agrário/Programa Nacional de Fortalecimento da Agricultura Familiar; Bahia - N. de } \\
\text { contratos e montante do Crédito Rural Pronaf por ano fiscal. }\end{array}$} \\
\hline
\end{tabular}

É delicado discutir sobre a gestão de políticas públicas na área de estudos pois o Território é cenário de duas realidades bastante distintas:

$$
\begin{aligned}
& \checkmark \text { áreas irrigadas que se concentram às margens do Rio São Francisco } \\
& \checkmark \text { áreas de sequeiro que são utilizadas principalmente para a criação de } \\
& \quad \text { caprinos e ovinos (minifúndios/fundos de pasto). }
\end{aligned}
$$

Nas áreas irrigadas a realidade fundiária é muito distinta das áreas de sequeiro. A irrigação se vale de um conjunto tecnologias que possibilita uma maior produtividade e maior produção em um espaço mínimo de terra.

Na região do TSSF é possível ter até três colheitas ao ano numa mesma área irrigada (uva).

Sendo assim, num panorâma geral que foi proposto neste trabalho teve um acompanhamento das transformações ocorridas pós 1996, quando foi instituído o PRONAF e que aqui pode -se destacar as mais intensas transformações a partir de 2002, pois no território, os serviços representaram 41,4\% no PIB para o ano de 2002. A agropecuária, $32,4 \%$. 
Em 2003 (SEI), o valor bruto da agropecuária atingiu R\$ 404,6 milhões. O município de Juazeiro representou 53,5\% do total do Território; Curaçá com 12,7\%; Sento Sé com 11,8\% e Casa Nova com 10,8\%. As principais culturas foram a uva, a manga, a cana-de-açúcar e cebola.

Já o rebanho, no ano de 2003 era composto por 2,5 milhões de cabeças, significando 16,3\% do total do estado da Bahia. Os caprinos representavam 50,8\% do total (maior rebanho da BA). No Território, 77,4\% são caprinos; 13,4\% bovinos (336 mil cabeças) e 9,2\% suínos (230 mil cabeças).

Dentre os produtos da lavoura temporária, nove deles merecem destaque: Cana-de-açúcar, feijão, mamona, mandionca, milho, tomate, cebola, melancia e melão.

Contudo, destaca-se que apenas três desses são cultivados nos dez municípios do Território de Identidade Sertão do São Francisco: Feijão, mandioca e milho.

Dos três, o feijão é o produto que ocupa maior área em cada um dos três maiores produtores do território: Remanso (4.733ha); Campo Alegre de Lourdes e Pilão Arcado com 4.100ha colhidos cada.

O milho também é dos três cultivos temporários que mais ocupam as terras dos municípios de Campo Alegre de Lourdes (4.667ha), Pilão Arcado (3.733ha) e Remanso (2.833ha).

Campo Alegre de Lourdes, Pilão Arcado e Remanso também são os municípios que apresentaram maior área colhida de mandioca (3.667ha; 3.067ha e 2.500ha, respectivamente). A pesar de serem esses os maiores produtores de mandioca, este produto da lavoura temporária é o mais rentável nos municípios de Canudos (6.283 mil reais), Uauá e Pilão Arcado. Portanto, se considerarmos os dez principais produtos da lavoura temporária, a mandioca é a mais importante no que se refere a produção e a renda para diversos municípios, além de ser cultivada em todos os municípios do Sertão do São Francisco.

Os produtos temporários como tomate, cebola e melancia apareceram em segunda ordem na ocupação das terras do território.

O tomate é cultivado em oito municípios é Juazeiro o que dedica maior área, em média 202 hectares. Em seguida aparecem Santo Sé e Curaçá com 85 hectares cada.

Já a cebola é o produto temporário de maior área plantada e também de maior rentabilidade do município de Casa Nova e Santo Sé. No primeiro, aparecem 2.108ha de área colhida e 22.172 mil reais e no segundo, uma área colhida de 2.001 ha e 23.415 mil reais. 
Já em Juazeiro a área é de 1.154ha e representa a segunda rentabilidade (10.188 mil reais) entre os cultivos temporários, atrás apenas da cana-de-açúcar.

Vale acrescentar que, a cebola também é a maior rentabilidade entre os cultivos temporários no município de Sobradinho.

Quanto a melancia, Juazeiro, Casa Nova e Curaçá são os três municípios com maior área colhida do produto, sendo destinados 868, 379 e 229 hectares nos municípios, respectivamente.

Juazeiro, Curaçá e Santo Sé são os municípios que mais destinam área de produtos temporários para o melão. Em Juazeiro 823ha, em Curaçá 461ha e em Santo Sé 438ha. Destaca-se que o melão é o cultivo temporário de maior rentabilidade para o município de Curaçá que obteve em média 3.622 mil reais.

A mamona aparece nos municípios de Santo Sé (428ha), Uauá (225ha) e Campo Alegre de Lourdes (223ha).

A cana-de-açúcar é o produto temporário que mais ocupa terras nos municípios estudados e é cultivada em quatro municípios: Canudos (15ha), Casa Nova (38ha), Pilão Arcado (160ha) e Juazeiro (16.610ha).

\section{Programa de irrigação}

Atualmente os perímetros irrigados são os de Mandacaru, Tourão, Curaçá, Maniçoba e Salitre (ainda em construção) configuram áreas diferenciadas, especialmente pela presença de grandes empresas que cultivam uva, manga e cana de açúcar.

TOURAO - lotes empresariais $(96,7 \%$ do total da área)

-Cana-de-açúcar praticada por uma única grande empresa, a Agrovale, que ocupa 17.000 hectares no projeto Tourão.

- 65 km de canais; 45 km de drenos; 42 km de estradas; 4 estações de bombeamento.

- CODEVASF - manutenção dos perímetros, controle e cobrança dos serviços de fornecimento de água e dos investimentos já realizados.

-Vale citar que a água retirada do Rio São Francisco não é cobrada (CODEVASF, 2010).

O Rio Salitre - O Projeto Salitre -CODEVASF 
O Salitre um rio histórico - suas margens primeira grande criação de gado no Brasil, que fornecia carne à sede da Colônia. Seu nome vem das jazidas de salitre, importante mineral no século XVII. Nascido na Chapada Diamantina era um raro exemplo de rio perene do semiárido brasileiro. Até os anos 1970, o vale fértil - legumes, frutas e hortaliças a Juazeiro e outras cidades.

- 1980 - novo tipo de conflito: pela água.

Afluente do São Francisco, o rio Salitre hoje tira água dele e "corre ao contrário" (SIQUEIRA, 2010).

- Projeto Salitre da Codevasf - Empresários. Em entrevista, em trabalho de campo, um representante da Codevasf afirmou que o projeto está sendo direcionamento para empresários e até mesmo doutores. Produtos para exportação e biocombustíveis (CODEVASF, 2009).

Para maior conhecimento da área de estudos a equipe preparou um resumo com as principais imagens coletadas nas três idas a área de estudo. Primeiramente, a profa Dra Noeli Pertile foi com os alunos da disciplina Humana II, em 2009.

Depois em março de 2010, a profa Dra Marcia Scheer também fez trabalho de campo e aproveitou para divulgar o projeto no Encontro Nacional de Enfrentamento a Desertificação realizado pelo Governo Federal e pela Univasf.

E por último, as professoras Dra Marcia Scheer e Denise Magalhães participaram do II WORKSHOP RIO SÃO FRANCISCO - Cultura, identidade e desenvolvimento: um olhar do ribeirinho sobre as mudanças no seu modo de vida. UNIVASF - Campus Juazeiro/BA. Nesta atividade foi feita de forma detalhada um relatório de viagem.

Também outros alunos que participaram de forma voluntária publicaram e apresentaram resumos em eventos sobre o tema do projeto, como pode-se comprovar pelo registro do Currículo Lattes da coordenadora e de outros professores da equipe, a seguir:

\section{Produtos gerados}

1. Neta Pergaminellis, Emília ; Scheer, M. A. P. S. ; Maia, Diego . A INFLUÊNCIA DO CLIMA 
NA VITICULTURA NA REGIÃO DO VALE DO SÃO FRANCISCO. In: IX Simpósio Brasileiro de Climatologia Geográfica - Climatologia e Gestão do Território, 2010, Fortaleza. Anais do IX Simpósio Brasileiro de Climatologia Geográfica, 2010. v. 1.

2. Lima, U D S ; Vaz, C B N ; Scheer, M. A. P. S. . Caracterização Geoambiental, Análise Integrada e avaliação dos impactos ambientais no Território de Identidade do Sertão do São Francisco (BA). In: XVI Encontro Nacional de Geógrafos, 2010, Porto Alegre. Anais do XVI Encontro Nacional de Geógrafos, 2010. v. 1.

3. Scheer, M. A. P. S. ; Pires, T. A . Sertão do São Francisco: mesmo território e diferentes identidades, 1970 a 2007. In: I Simpósio Cidades Médias e Pequenas da Bahia, 2009, Salvador. I Simpósio Cidades Médias e Pequenas da Bahia, 2009. v. 1.

4. CELESTINO, L. F. ; Scheer, M. A. P. S. . A Fruticultura no desenvolvimento do Território de Identidade Sertão do São Francisco (BA). In: XXVII Seminário Estudantil de Pesquisa/ IX Seminário de Pesquisa e Pós-Graduação, 2008, Salvador. XXVII Seminário Estudantil de Pesquisa/ IX Seminário de Pesquisa e Pós-Graduação - Universidade Federal da Bahia, 2008.

5. Pires, T. A ; Scheer, M. A. P. S. . Estudo da produção agrícola do Território de Identidade do Sertão do São Francisco 2004 a 2006: Uma análise integrada com as imagens orbitais do satélite SPOT 4-Vegetation.. In: XXIX Seminário Estudantil de Pesquisa - XI Seminário de Pesquisa e Pós-Graduação, 2010, Salvador. XXIX Seminário Estudantil de Pesquisa - XI Seminário de Pesquisa e Pós-Graduação, 2010. v. 1.

6. CELESTINO, L. F. ; Scheer, M. A. P. S. ; JeSUS, E. F. R. ; GONCALVES, N. M. S. . As interrelações da Produção Agrícola Municipal (PAM) e do Programa Nacional de Fortalecimento da Agricultura Familiar (PRONAF) na análise da transformação do espaço agrário: Território de Identidade Sertão do São Francisco (BA), 2004 - 2006. In: XV Encontro Nacional de Geógrafos, 2008, São Paulo. XV Encontro Nacional de Geógrafos, 2008.

7. Scheer, M. A. P. S. ; MAGALHAES, D. . Análise do Território de Identidade Sertão do São Francisco (BA) via metodologia de Integração em Ambientes SIG. RDE. Revista de 
Desenvolvimento Econômico (Edição Especial), UNIFACS, Salvador (BA), 2011. (PRELO)

EVENTOS: $\quad$ Scheer, M. A. P. S. ; LAGE, C. ; Melo, Danilo ; MAGALHAES, D. ; JESUS, E. F. R. ; Germani, G ; PERTILE, N. . III Seminário de Estudos Ambientais e Ordenamento Territorial - "Estratégias de investigação geográfica aplicadas ao território: o semiárido baiano", UFBA, 2010.

Foram convidados inúmeros professores e pesquisadores de diferentes Órgãos Públicos e Privados que se dedicam ao estudo do semiárido.

9. 2o CARTOGEO - II Simpósio Internacional Caminhos Atuais da Cartografia na Geografia.Mesa redonda: Tecnologia da Informação Geográfica ("SIG aplicado ao estudo do semiárido baiano"). 2010. (Simpósio). Nesta palestra foram apresentados os resultados da pesquisa.

10. I Encontro Nacional de Enfrentamento à Desertificação.Representante da comunidade científica. Divulgação do projeto de pesquisa desenvolvido sobre o Território de Identidade Sertão do São Francisco (BA). 2010. (Encontro).

11. PERTILE, N. . A produção do espaço e a conflitualidade territorial no campo baiano. 2010. (Apresentação de Trabalho/Conferência ou palestra).

12. PERTILE, N. . Para quem e como está organizado o espaço rural no Sertão do São Francisco: breves considerações. 2010. (Apresentação de Trabalho/Conferência ou palestra).

\section{CONSIDERAÇÕES FINAIS}

Deve-se ressaltar que, a originalidade desta proposta consistiu no esforço de articulação de diferentes metodologias de análise, visando o desenvolvimento de um modelo que possibilite melhores aproximações analíticas com a realidade. 
Com a conclusão desta pesquisa, pretende-se divulgar as deficiências como também o que aquele lugar tem de bom, gerando subsídios que auxiliarão, sobremaneira, no processo de planejamento, minimizando diferentes tipos de impactos sofridos na área estudada.

Quanto aos produtos gerados, sofremos ajustes durante sua elaboração e também com o processamento das imagens, por isso não conseguimos avançar muito na parte teórica do trabalho, por exemplo: na discussão de conceitos, (mas que é nosso próximo propósito) entretanto, tivemos a partir de abril de 2010 uma colaboração inesperada, com a concessão de 10 bolsas para o Programa de Incentivo à Docência (PIBID/CAPES) o que fez com que os alunos bolsistas se envolvessem com a parte pedagógica em conviver com o semiárido ao invés de desvalorizá-lo, aplicando atividades nas escolas de Salvador envolvendo o tema. Também os alunos estão finalizando uma Cartilha Paradidática, para que possamos continuar o trabalho em 2011, em forma de oficinas, uma possível publicação via PIBID e também divulgação em Prefeituras, Organizações não Governamentais e Religiosas que tenham liderança na área de estudo.

Também foram aplicados mais de 30 questionários à especialistas na área de estudo, durante os trabalhos de campo, que irão auxiliar no ajuste do Sistema de Informação Geográfica, o tornando mais coerente com a realidade, porém esta será uma próxima etapa a ser enviada num projeto futuro.

Muito obrigada pela confiança e também pelo recurso financeiro, pois sem ele não seria possível esta pesquisa sair do papel.

Por fim, realizamos em conjunto com o PIBID/Geografia o III Seminário do Estudos Ambientais e Ordenamento do Territorial: "Estratégias de investigação geográfica aplicadas ao território: o semiárido baiano" nos dias 8 e 9 de novembro deste ano. Convidamos vários especialistas no assunto, inclusive a conferência de abertura foi realizada pelo Prof Dr Jansle Vieira Rocha da Unicamp (que deu a idéia inicial desta pesquisa). Foi um evento muito importante, pois discutimos sobre a valorização de uma área que, infelizmente, várias pessoas que tem melhores condições financeiras se sobressaem e acabam explorando os desprovidos. A conscientização é muito importante para toda a população que convive e tem como sustento o sertão baiano e a nossa parte está em ajudar a conscientizar este povo, principalmente, através da educação. 


\section{BIBLIOGRAFIA}

ACCARINI, H. J. Economia Rural e Desenvolvimento. Petrópolis: Editora Vozes, 1987.

AB'SABER, A. Dossiê Nordeste Seco. Estudos Avançados 13 (36), 1999.

ANDRADE, M. C. A terra e o homem no nordeste, hoje. Conferência pronunciada na 55a Reunião Anual da SBPC, Recife, 2003.

ASSAD, E. D.; SANO, E. E. Sistema. Sistema de informações geográficas: aplicações na agricultura. Brasília: EMBRAPA, 1993.

AYYAR, N. P. Crop regions of Madhya Pradesh - a study in methodology. Geographical Raview of India, v. 31, n. 1, p. 1 - 19. Calcuta, 1969.

AYOADE, J. O. Introdução a climatologia para os trópicos. São Paulo: Difel, 1981.

BAHIA. Territórios de Identidade 2007. Disponível em: <http://www.sei.ba.gov.br>. Acesso em: 07 jul. 2010.

BOMFIM, J. D. Movimentos sociais de trabalhadores no rio São Francisco. Scripta Nova Revista Electrónica de Geografia y Ciências Sociales. Universidad de Barcelona [ISSN 11389788], n. 45 (30), 1 de agosto de 1999.

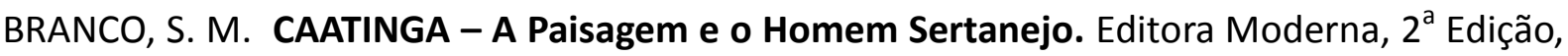
2003.

BURROUGH, P. Principles of geographical information systems for Land Resources Assessment. OXFORD: New York, 1986.

CALDAS, A. S. Globalização em territórios periféricos: os sistemas produtivos rurais da Bahia e da Galícia. Salvador: UNIFACS, 2006. 274 p. : il.

Castro, I. E; GOMES, P. C; CORREIA, R. L. Geografia: Conceitos e Temas. 12a Edição, Rio de Janeiro: Bertrand Brasil, 2009.

CAVALCANTI, I; FERREIRA, N; Silva, M; Dias, M. Tempo e Clima no Brasil. São Paulo: Oficina 
de Textos, 2009.

CHRISTOFOLLETI, A. Modelagem de sistemas ambientais. São Paulo: Edgard Blucher, 1999.

Companhia de Desenvolvimento dos Vales do São Francisco e do Parnaíba. Perímetros irrigados: Projeto Tourão. Disponível em: http://www.codevasf.gov.br/principal/perimetrosirrigados/elenco-de-projetos/tourao. Acesso em: 28 de setembro de 2010.

CREPANI, E; MEDEIROS, J. S; HERNANDEZ FILHO, P; DUARTE, V, BARBOSA, C. C.F. Sensoriamento Remoto e Geoprocessamento aplicados ao zoneamento ecológicoeconômico e ao ordenamento territorial. São José dos Campos: Instituto da Ciência e Tecnologia - Instituto Nacional de Pesquisas Espaciais, Junho de 2001.

CROSTA, A. P. Processamento digital de imagens de sensoriamento remoto. Campinas: UNICAMP, 1992.

CUNHA, E. Os Sertões. 1901.

DREW, D. Processos interativos homem-meio ambiente. Tradução de João Alves dos Santos. São Paulo: Difel, 1986.

FITZ, P. R. Geoprocessamento sem complicação. São Paulo: Oficina de Textos, 2008.

GERARDI, L. H.; SILVA, B. Quantificação em Geografia. São Paulo: Difel, 1981.

LEFF, E. Ecologia, Capital e Cultura. A territorialização da racionalidade ambiental. Editora Vozes, 2009.

FLORENZANO, T. G. Iniciação em Sensoriamento Remoto. 2a Edição. São Paulo: Oficina de Textos, 2007.

GOVERNO DO ESTADO DA BAHIA. Bacias Hidrográficas da Bahia - Superintendência de Recursos Hídricos. Edição Atualizada, 2006

LIU, W. T. H. Aplicações de Sensoriamento Remoto. Campo Grande: Editora Uniderp, 2006.

LOCH, R. E. N. Cartografia: representação, comunicação e visualização de dados espaciais. 
Florianópolis: Editora da UFSC, 2006.

MARTINE, G; GARCIA, R. C. Os impactos sociais da modernização agrícola. São Paulo: Editora Caetes, 1987.

MENDONÇA, F. Geografia Socioambiental. São Paulo: Terra Livre, 16, p. 113-132, 1o semestre de 2001.

MENDONÇA, F; DANNI-OLIVEIRA, I. M. Climatologia - noções básicas e climas do Brasil. São Paulo: Oficina de Texto, 2007.

MINISTÉRIO DO MEIO AMBIENTE. Atlas das áreas susceptíveis à desertificação do Brasil. Brasília: MMA, 2007.

MONTEIRO, J. E. B. A Agrometeorologia dos Cultivos. O fator meteorológico na produção agrícola. Brasília: INMET, 2009.

ORELLANA, M. M. P. Metodologia integrada no estudo do meio ambiente. Geografia, 10 (20), p. $125-145$, outubro de 1985.

NOVO, E. M. L. M. Sensoriamento remoto: princípios e aplicações. São Paulo: Edgard Blucher, 2008.

PERTILE, Noeli. Trabalho de campo com alunos da Graduação em Geografia na disciplina Geografia Humana II, nos municípios de Juazeiro e Petrolina. Entre 11 e 14 de novembro de 2009 .

PORTO-GONÇALVES, C. V. A globalização da Natureza e a Natureza da Globalização. Rio de Janeiro: Civilização Brasileira, 2006.

RAFFESTIN, C. Por uma geografia do poder. São Paulo: Ática, 1993.

ROSS, J. L. S. Ecogeografia do Brasil. Subsídio para Planejamento Ambiental. São Paulo: Oficina de Texto, 2006.

ROSS, J. L. S. Geografia do Brasil. 6ạ Edição. São Paulo: Edusp, 2009. 
SANTOS, M. et al. Território, territórios: ensaios sobre o ordenamento territorial. Rio de Janeiro: DP\&A Editora, 2006.

SAQUET, M. A Abordagens e Concepções de Território. 2a Edição. Editora Expressão Popular, São Paulo, 2010.

SILVA, S. C. B. M.; SILVA, B. C. N. Estudos sobre globalização, território e Bahia. 1 ed. Salvador: Mestrado em Geografia da UFBA, 2003. v. 1. 182 p.

SIQUEIRA, Ruben. Conflito pela água no Rio Salitre, 30/09/2010. CPT, 2010.

Disponível:

http://www.cptba.org.br/index.php?option=com content\&view=article\&id=484:conflitopela-agua-no-rio-salitre\&catid=8:noticias-recentes\&ltemid=6 acesso em: 30/09/2010.

SCHEER, M. A. P. S. et al. Geoprocessamento como estratégia de investigação do espaço geográfico: uma abordagem socioambiental aplicada ao Território de Identidade Sertão do São Francisco (BA), 2004 a 2006. 2008. 12 f. Projeto de Pesquisa (Mestrado em Geografia) Departamento de Geografia/Instituto de Geociências, Universidade Federal da Bahia, Bahia, 2008.

SOUTO JÚNIOR, J. F. O Vale Encantado do São Francisco. Inédito, UNIVASF, 2010.

SUPERINTENDÊNCIA DE ESTUDOS ECONÔMICOS E SOCIAIS DA BAHIA. Estatística dos municípios baianos. Volume 7. Território de Identidade Sertão do São Francisco. Salvador: SEI, 2010.

Superintendência de Estudos Econômicos e Sociais da Bahia. Uso atual das terras: Bacias da margem direita do lago de Sobradinho. Salvador: SEI, 2009

SUPERINTENDÊNCIA DE ESTUDOS ECONÔMICOS E SOCIAIS DA BAHIA. Anuário Estatístico da Bahia. Salvador: SEI, 2003.

SUPERINTENDÊNCIA DE ESTUDOS ECONÔMICOS E SOCIAIS DA BAHIA. Análise dos atributos climáticos do estado da Bahia. Salvador: SEI, 1998. 85 p. (Série Estudos e Pesquisas, 38). 
TRICART, J. Ecodinâmica. Série Recursos Naturais e Meio Ambiente. Rio de Janeiro: IBGE, 1977.

TROPPMAIR, H. Biogeografia. 7ạ Edição. Rio Claro: Edição do autor, 2006.

VAZ, C. B. N.; PERTILE, N.; LIMA, U. D. S. Relatório de campo no vale do São Francisco: vivendo do ou vivendo com o semi-árido. Revista Discente Expressões Geográficas, Florianópolis, no 06, ano VI, p. 173 - 185, junho de 2010.

\section{ANEXOS}

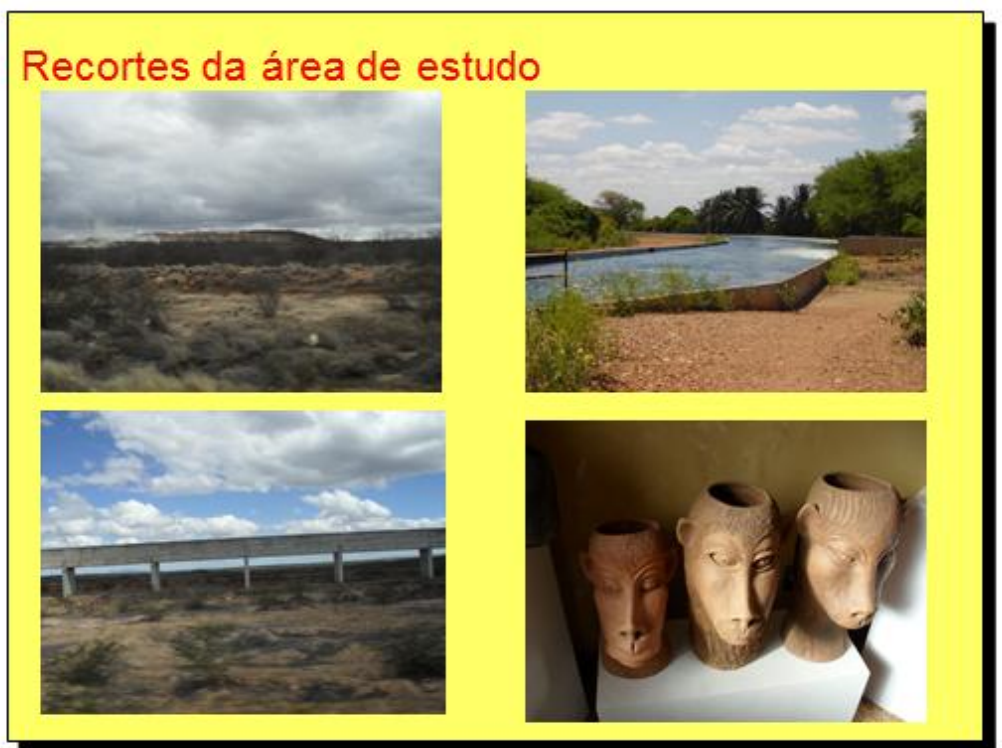

Da esquerda para direita:

1. Caatinga - Bahia

2. Canal de irrigação no solo - Juazeiro

3. Canal de irrigação suspenso - caminho à Casa Nova

4. Esculturas de Carrancas da Ana das Carrancas, museu em Petrolina -PE. 


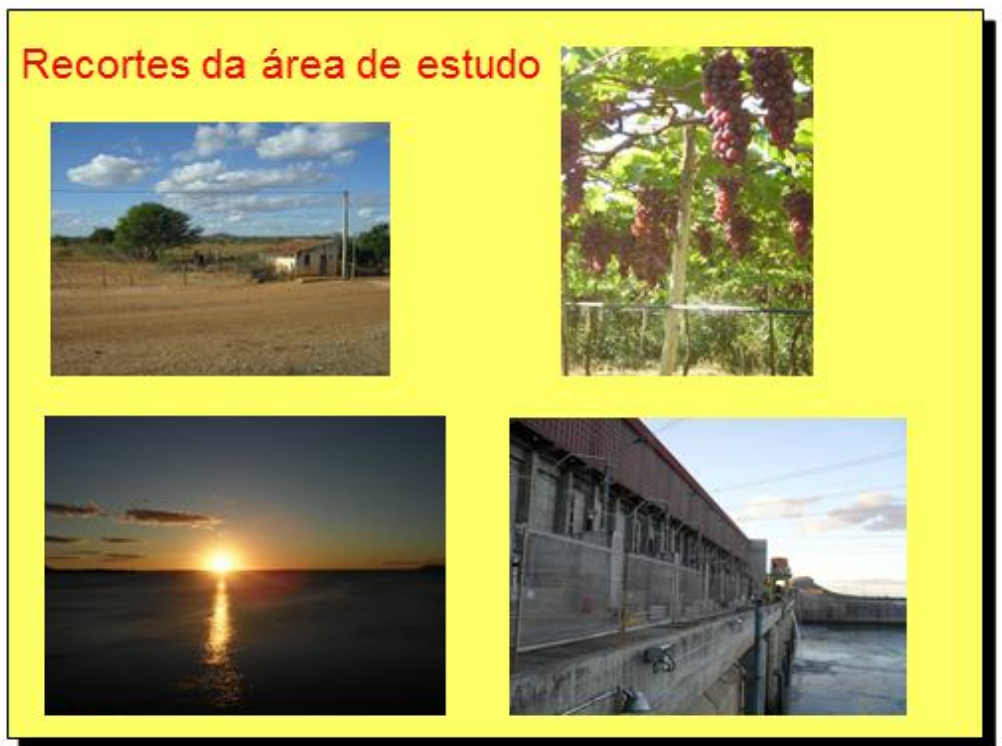

Da esquerda para direita:

5. Casa no campo

6. Parreiral de Uvas Ouro Verde (Casa Nova)

7. Pôr do Sol em Sobradinho - BA

8. CHESF (saída da água das turbinas). 